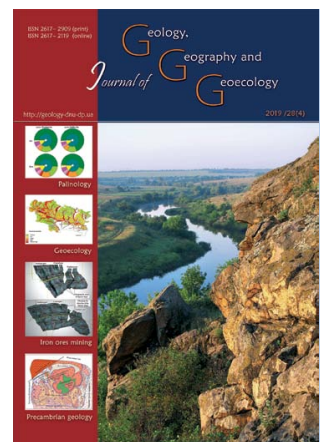

Journal of Geology.

\title{
Location pattern and genetic classification of granite pegmatites of the Ukrainian Shield
}

\author{
Leonid V. Isakov, Maria L. Isakova \\ National Technical University Dnipro Polytechnic, Dnipro, Ukraine, isakov_l@ukr.net
}

Received: 17.02 .2019

Received in revised form: 04.03.2019

Accepted: 20.09.2019

Abstract.The pegmatites of the Ukrainian Shield, their formation and occurrence are considered. It is shown that the Ukrainian Shield is a pegmatite province encompassing seven regions: Middle Prydniprovia, Western Pryazovia, Eastern Pryazovia, Ingulski, RosynskoTikytski, Dnistersko-Buzki and Volyn, respectively encompassing megastructures of the same names and including pegmatite fields of different mineralogical composition and geochemical specialization. The Volynski, Ingulski, Middle Prydniprovia, Western Pryazovia regions have rare-earth and rare-metal specialization presented by pegmatites of different origin and petrological and mineral composition and occurring in different structural and tectonic conditions, having different formation age, which allows a full classification scheme of the pegmatites of Ukrainian Shield to be given. These structures can be considered as having formed as a result of abyssal magmatic plumes. The geological-structural position of these megastructures with obvious signs of influence of certain abyssal processes on their formation supports this assumption. We present the main geological structural and genetic factors of formation of pegmatite-bearing megastructures of the Ukrainian crystalline core-area, these factors forming the basis of a classification scheme of pegmatites of Pre-Cambrian shields. We have systematized the pegmatites of the Ukrainian Shield, and designed their classification scheme. We have distinguished the following groups of pegmatites by the development of pegmatite-generating zones: - three genetic groups of pegmatites: ultrametamorphogenic, magmatogenic and metamorphogenic-metasomatic; - six genetic subgroups of pegmatites: migmatic; autochthonous granite massifs; metamorphogenic and metasomatic displaced and formed pegmatites; multiphase intrusive granite massifs; multiphase intrusive alkaline massifs; multiphase granite batholiths. By the nature of pegmatite-bearing structures, the following structural groups have been singled out: granite-gneiss regional structures and domes; domesynclinore and dome-trough plume-structures (subgroups: interdome synclinore and trough structures, in particular greenstone structures; intrusive domes and batholiths); specific tectonic zones of stress tensions.

Keywords: Ukrainian pegmatite province, Volyn, Ingulets, Middle Prydniprovia and Western Priazovia pegmatite regions, gneiss granite dome-shaped structure, synclinore, greenstone belt, pegmatites, classification of pegmatites.

\section{Закономірності розміщення і генетична класифікація гранітних пегматитів Українського щита}

\author{
Л.В. Ісаков, М.Л. Ісакова
}

Національний технічний університет «Дніпровська політехніка», Дніпро, Україна, isakov_l@ukr.net

Анотація. Розглянуто пегматити Українського щита, закономірності їх формування та розміщення. Показано, щоУкраїнський щит (УЩ) є пегматитовою провінцією, яка об’єднує сім районів: Середньопридніпровський, Західноприазовський, Східноприазовський, Інгульський, Росинсько-Тікицький, Дністерсько-Бузький і Волинський, які відповідно охоплюють однойменні мегаструктури і несуть пегматитові поля насичені пегматитами різного мінералогічного складу і геохімічної спеціалізації. Середньопридніпровський, Західноприазовський, Інгульський і Волинський райони представлені пегматитами різного генезису і петролого-мінералогічного складу та розміщуються в різних структурно-тектонічних умовах, мають різний вік формування, що дає змогу на основі їх систематизації надати повноцінну класифікаційну схему пегматитів Українського щита. Мегаструктури, що складають ці пегматитові райони, можна вважати такими, що утворилися внаслідок дії глибинних магматичних плюмів. На користь такого припущення свідчить геолого-структурна позиція мегаструктур з чітко вираженими ознаками впливу на їх формування специфічних глибинних процесів. Відображені основні геолого-структурні та генетичні чинники формування пегматитоносних гранітних комплексів мегаструктур покладені в основу розробленої класифікаційної схеми пегматитів древніх докембрійських щитів. Проведено систематизацію і складено класифікаційну схему пегматитів Українського щита. За розвитком пегматитогенерувальних осередків виділено: - три генетичні групи пегматитів: ультраметаморфогенні, магматогенні і метаморфогенно-метасоматичні; - шість генетичних підгруп пегматитів: мігматитові; автохтонних гранітних масивів; метаморфогенно і метасоматично заміщені й утворені пегматити; багатофазних 
інтрузивних гранітних масивів; багатофазних інтрузивних лужних масивів; багатофазних гранітних батолітів. За характером пегматитовмісних структур виділено такі структурні групи: гранітогнейсових регіональних структур і куполів; купольносинклінорних i купольнотроговихплюмструктур (підгрупи: міжкупольнісинклінорні i трогові, зокрема зеленокам'яні структури; інтрузивні куполи і батоліти); специфічних тектонічних зон стресових напруг.

Ключові слова: Украйнська пегматитова провіниія, Волинський, Інгульський, Середньопридніпровський $і$ Західноприазовський пегматитовий район, гранітогнейсові куполи,синклінорії, зеленокам'яні пояси, пегматити, систематизація пегматитів.

Introduction. Fundamental issues of geological and structural laws of formation of granite pegmatite fields and their occurrence in these fields lie at the basis of studies aimed at revealing the areas of development of pegmatite fields, their separate nodes and bodies and grounded prognostic exploration of rare metals and ceramic raw materials. Pegmatites of PreCambrian complexes are the main indicators of commercially viable abundance of a range of rare metal elements, for some of them being the only indicator. In particular, according to statistics, from 73 to $92 \%$ of all reserves of $\mathrm{Li}, \mathrm{Rb}, \mathrm{Cs}, \mathrm{Be}$ and Ta concentrated in pegmatites occur in Pre-Cambrian complexes.

There is a general classification of development process of pegmatite formation and Pre-Cambrian pegmatite field formation; this classification takes into account geological-structural and historicalgeological features of earth crust development in the Archean, which allows further clarification of the sequence of geological processes influencing not only the structure and composition of separate pegmatite bodies and their conglomerates, but also the formation of pegmatite-bearing geoblocks of shields; this classification also allows one to answer certain fundamental general geological questions concerning the development of pegmatite-bearing territories and the earth's crust in general. Taking into account the link of pegmatites with both ultrametamorphic autochthonous granite complexes and intrusive granites, understanding of the laws of their formation will help clarify a set of important questions concerning the evolution of granitoid magmatism in the Pre-Cambrian.

Analysis of recent papers. Since the first scientific description and study of pegmatites (by E.Patrin in 1791 and V. Severin in 1798) and the singling out of graphic granite as a separate mineral called "pegmatite" by R. Gauyi in 1801, several important stages of its study can be distinguished. The first important stage in pegmatite study started in the early $20^{\text {th }}$ century and lasted till 1931, the year when "Pegmatites" - a fundamental monograph by O.Fersman - was published. This period was characterized by the buildup of published research on the geology of pegmatites - from the description of mineral forms and internal structure of bodies, to definition and characterization of pegmatite fields.
The next stage of pegmatite study, which started right after the above mentioned monograph and reached its climax in the mid 1940s, was connected with the expansion of commercial demand for rare metals, during which pegmatites, being the ores for these metals, were available and easily identified. The huge amount of scientific papers published in this period made it possible to create a separate branch of geological science - the study of pegmatites. At that time, on the basis of different viewpoints on the genesis of pegmatites there formed three scientific schools in the study of pegmatites. The representatives of the first school considered pegmatites to be the products of crystallization of residual molten-dilution of its intrusion from the main massif and gradual crystallization in the isolated system without significant introduction of external matter. V.Bregger, A.Lacrios, I.Gott and others were among the advocates of this theory, O.Fersman developed this idea, later supported by the research of K.Vlasov, I.Ginsburg, M.Solodov, I.Nedumov and others. Representatives of the second school regarded the formation of pegmatites as stemming from metamorphic and ultrametamorphic transformations. These include P.Eskola, D.Korzhynski, N.Sudovikov, Yu.Sokolov and other researchers mainly studying Pre-Cambrian pegmatites. The third school interpreted pegmatites as the product of recrystallization and metasomatic transformation of aplites, bastard granite and formation of pegmatite bodies under the influence of postmagmatic solutions in the open system. The most well-known representatives of this school are V. Sheller, F. Hess, K. Lendon, O.Zavarytski, A. Nikitin and others.

Since the 1960s, a range of fundamental studies dedicated to the study of pegmatites has been published. The most important generalizing works that actually formulated the modern study of pegmatites are connected with names of I. Ginsburg, K.Vlasov, M. Solodov, I.Nedumov, M.Kuzmenko, A.Nikitin, V.Arhangelska, Yu.Sokolov, V.Petrov, A. Kalita, Ye. Lazarenko, V.Pavlyshyn, G. Rodionov, K. Babaiev, B. Shmakin, S. Shavlo, Yu.Yurk, L.Feldman and others.

The appearance of fundamental works by the above researchers was the turning point indicating the beginning of the fourth generally theoretical period of development of the study of pegmatites. These works 
formulated the main points of the pegmatite question, in particular: the geological structure of pegmatite belts, fields, nodes; the regularities of their occurrence and development; granite magmatism and pegmatite formation; influence of metamorphic, metasomatic, hydrothermal processes on the pegmatite formation; internal structure of pegmatite bodies and the conditions of their formation; mineral composition of pegmatites; geochemistry of pegmatites and evolution of geochemical processes; physical and chemical conditions of pegmatite formation; experimental modeling; practical issues of pegmatite exploration and use.

Historical study of pegmatites of the Ukrainian Shield dates back to the first quarter of the $20^{\text {th }}$ century; however, serious research on them started only 70 years ago. During 1930-50s the research works were scattered and mainly aimed at the study of pegmatites as ceramic raw materials, except for the Korostensky pluton, where starting from 1931 geologicalprospecting operations of chamber pegmatites began. Systematic research on pegmatites as rare metal raw materials started in the 1960s. Thanks to the joint efforts of industrial and research groups, in 1960-90s and at the beginning of the $21^{\text {st }}$ century, large- and medium-scale geological and prognostic-metallogenic maps of the Eastern part of the Ukrainian Shield were created, a huge amount of factual material about different types of pegmatites was collected, the main directions of prospecting works for rare-earth metals, quartz and jewelry raw materials (topaz, beryl), and ceramic raw materials in pegmatites were determined. The following outstanding researchers of pegmatites should be mentioned: L.Lavrynenko, V.Kychurchak, L.Isakov, O.Koval, G.Lepigov, N.Viatkin, P.Shramko, S.Shutov, V.Kyshurchak, V.Pustovoitov, V.Kinshakov, V.Shpilchak, B.Ivanov, O.Lysenko, V.Lysenko, O.Makivchuk,V.Bezvynni, G.Lepigov, V.Mokiets.

At the same time, pegmatites of the Ukrainian Shield were studied by the following scientists and researchers; E.Lazarenko, M.Semenenko, Yu.Yurk, V.Pavlyshyn, B.Zatsiha, L.Isakov, M.Ivantyshyn, G.Kniazev, V.Kichurchak, L.Lavrynenko, K.Lytovchenko, K.Rozanov, S.Shavlo, N.Yashchenko and others. Their findings are presented in numerous papers and monographs, in particular: E.Lazarekno, V.Pavlyshyn, Yu. Sorokin."Mineralogia i genesis kamernyh pegmatitov ["Mineralogy and genesis of chamber pegmatites"], 1973; Ye.Lytovchenko."Granitnie pegmatity Zapadnogo Priazovia" ["Granite pegmatites of Western Pryazovia"], 1976; K.Rozanov, L.Lavrynenko."Redkometalnie pegmatity Ukrainy" ["Rare metal pegmatites of Ukraine"], 1979; S.Shavlo, G.Kniaev, S.Kirikilitsa."Granitnye peg- matity Ukrainy" ["Granite pegmatites of Ukraine"], 1984; "Kriterii prognozirovania mestorozhdeni Ukrainskogo shchita i ego obramlenia" ["Criteria of forecasting deposits of the Ukrainian Shield and its margins"], 1980 (ed. by M.Semenenko); "Mineralogia Priazovia" ["Mineralogy of Pryazovia"], 1980 (ed. by Ye.Lazarenko); L.Isakov "Polia granitnyh pegmatytiv Zakhidnogo Pryazovia" ["Granite pegmatite fields of the Western Pryazovia"], 2007 and oth. Under the supervision of S.Shavlo, Institute of Mineral Resources, maps of the pegmatite fields of the Ukrainian Shield were created and criteria of forecasting pegmatite related mineralization were developed $(1973,1980)$; in 2004 this work was resumed under the supervision of L. Isakov in Ukrainian State Geological Prospecting Institute, resulting in 2008 in a topical report on pegmatites of the Western Pryazovia and Middle Prydniprovia. Unfortunately, further work was suspended due to the lack of financing.

Geological-prospecting and scientific research work resulted in the discovery of a group of Volyn deposits of chamber pegmatites (quartz, topaz, beryl) within the Korostensky pluton of the Volyn megablock (in the 1930s - 1940s); in the 1960s came the discovery of the rare metal deposit of pegmatites "Krutaia Balka" attributed to the central part of Sorokynska tectonic zone; in the 1980s - 1990s, the Shevchenkivske deposit of lithium pegmatites within the Shevchenkivsko-Fedorivska structure was discovered; discoveries included a range of prospective occurrence of rare metals in pegmatites of the Sorokynska structure, the Shevchenkivska and Fedorivska structure and rare earth metals in pegmatites of the Gaichur structure of the Western Pryazovia megastructure; occurrences of rare-metal pegmatites of the Komendantivska and Zhovtovodska structure of the Middle Prydniprovia megablock; rare metal pegmatites of the Ingulski megablock: Polokhivske and Stankuvatske pegmatite fields (Polohivske, Nadia and Stankuvatske deposits);occurrences of rare-metal pegmatites of Mostove and Vys pegmatite fields.

General information and regionalization of Ukrainian pegmatite province. The generally accepted hierarchy scheme of pegmatites is as follows: pegmatite $>$ pegmatite node $>$ pegmatite field $>$ pegmatite belt $>$ pegmatite region $>$ (pegmatite area) $>$ pegmatite province. According to this scheme, the Ukrainian Shield is a pegmatite province encompassing seven regions: Middle Prydniprovia, Western Pryazovia, Eastern Pryazovia, Ingulski, Rosynsko-Tikytski, DnisterskoBuzki and Volyn (Fig.1, geological basis (Tectonic map, 2006, Drannyk, 2003), respectively encompassing megastructures of the same names. 


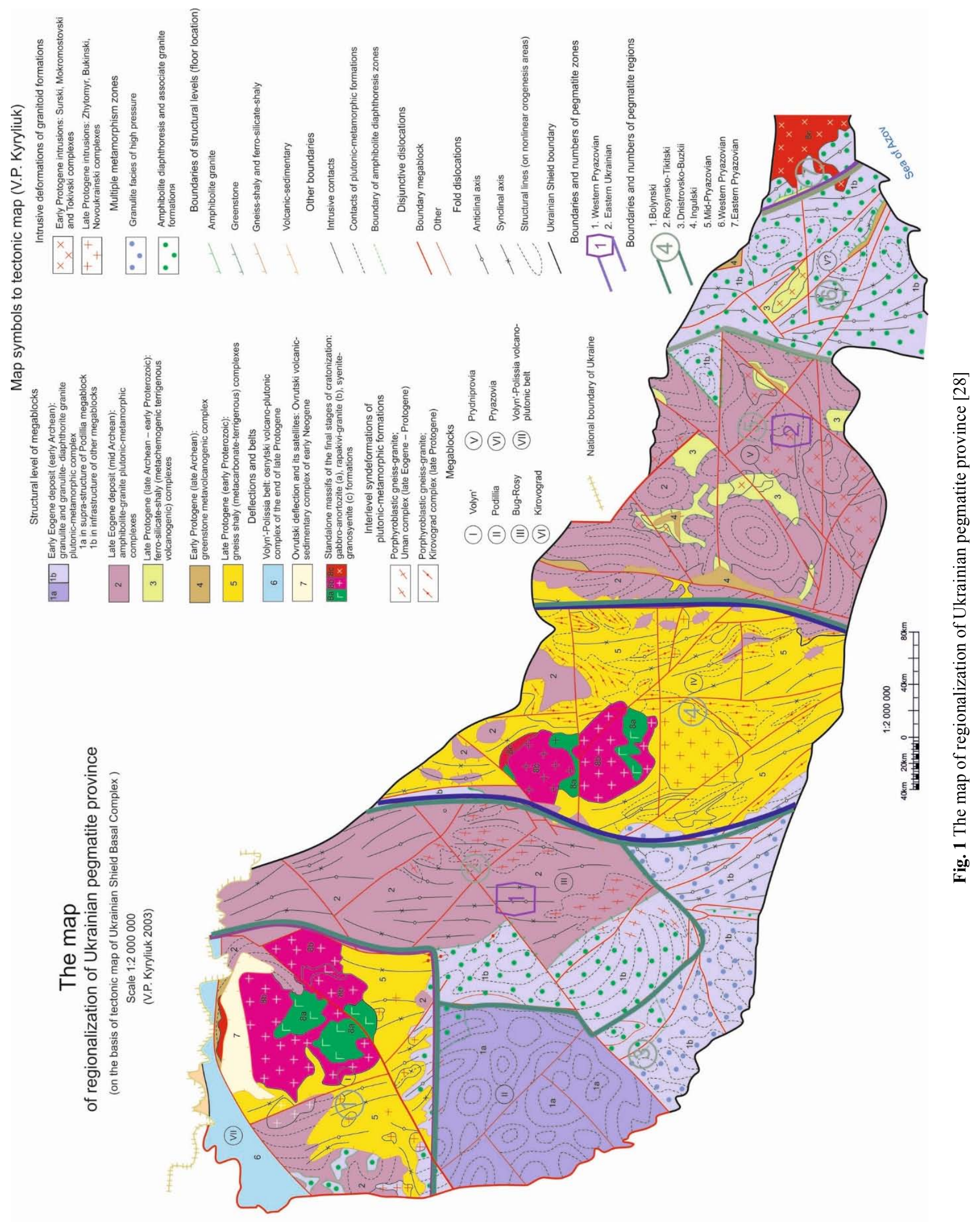


We combine the Western Pryazovia and Middle Prydniprovia regions (Isakov, 2013) into the Eastern Ukrainian pegmatite area, as both these structures had a similar or probably common development during its mass formation of pegmatites, which resulted in the formation of pegmatite belts (Fig.2).

We also, for our purpose, have combined the Rosynsko-Tikytski and Dnistersko-Buzki regions into the Western Ukrainian pegmatite area. These regions at the moment are associated with ceramic specialization with rare earth geochemical specialization .However, on the basis of separate geological-structural constructions of the Rosynsko-Tikytski megastructure (greenstone formations are not excluded), and taking into account the considerable influence of granite massifs of the Korostenski pluton in its northwestern part, the development of pegmatite fields of rare metal specialization is quite possible within the structure. Nevertheless, the pegmatites discovered within the boundaries of this area are homogeneous and are attributed to ultrametamorphic migmatite and granite complexes. We are not going to focus on these two areas except for the above statement. Taking into account the geological-structural development of the Eastern Pryazovia area, and the presence of complex granite and alkaline intrusions within its boundaries, this area also belongs to the promising areas containing rare-earth pegmatites, although, unfortunately, considerable occurrences have not been found so far.

The Volynski, Ingulski, Middle Prydniprovia, Western Pryazovia regions have rare-earth and rare-metal specialization. These structures can be considered as having formed as a result of abyssal magmatic plumes. The geological-structural position of these megastructures with obvious signs of influence of abyssal processes on their formation is

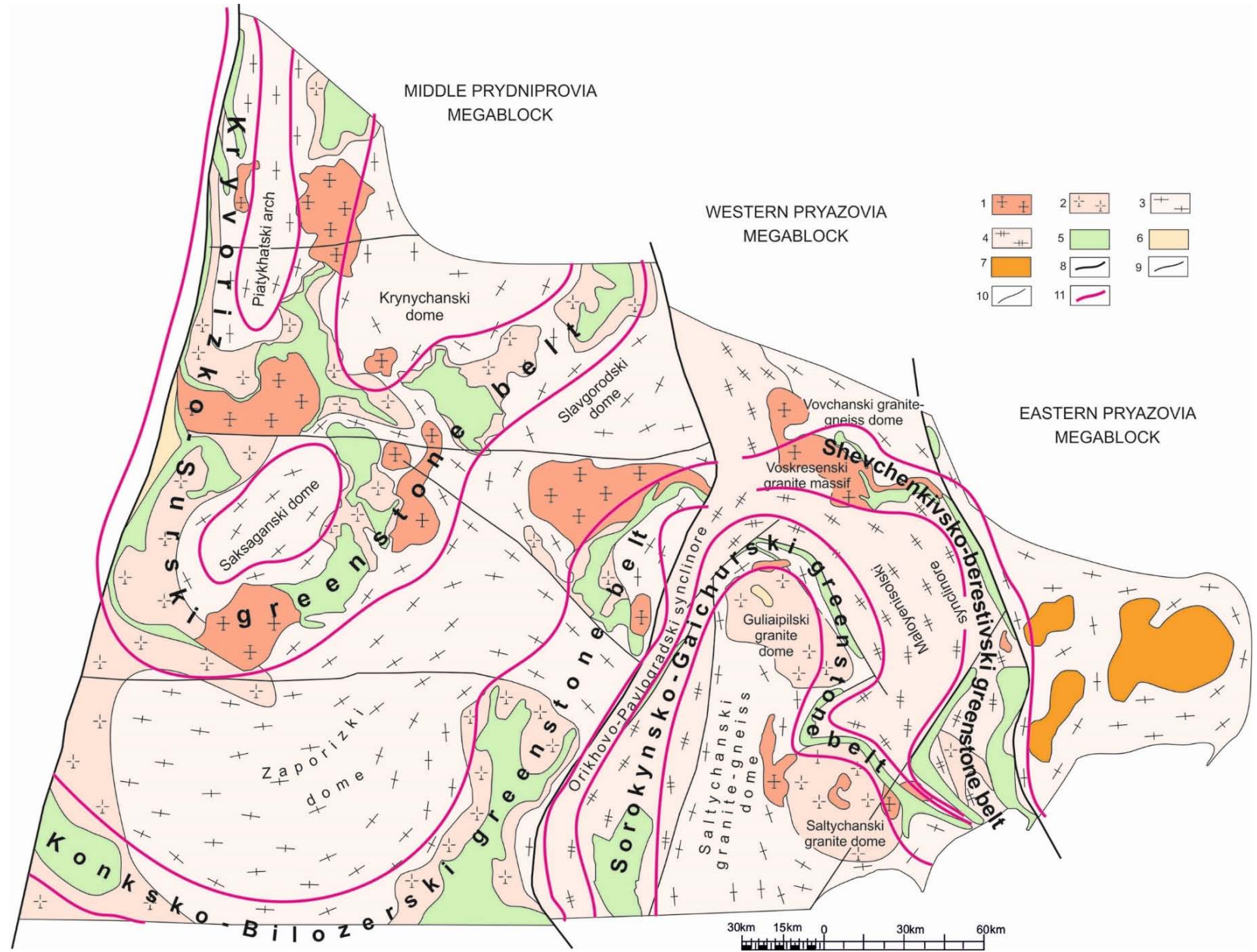

Fig. 2. Contour map of geological structure of the Eastern part of the Ukrainian Shield.

1 - two-feldspar granites of the Demurski, Tokivski, Mokromoskovski, Dobropilski, Saltychanski and Yanvarski complexes; 2 - plagiogranites, tonalites of Surski, Saksaganski and Shevchenkivski complexes; 3 -metamorphic series (Aulska and Western Pryazovska) and ultrametamorphic complexes (Slavgorodski, Novopavlivski and Dnipropetrovski) of dome structures; 4 - metamorphic formations (Vovchanska and Dragunska), Central Pryazovia series and ultrametamorphic complexes (Remivski and Tokmatski) of sutural zones; 5 - metamorphized igneous-terrigenous complexes of trough structures of greenstone type (Konkska, Bilozerska, Osypenkivska series and Novogurivska, Ternuvatska, Kosivtsivska formations); 6 - terrigenous complexes of fault-line superimposed structure (Kryvorizka series, Guliapilska suite); 7 - gabbro, monzonites, syenites of Southern Kalchytski and Oktiabrski alkaline intrusive complexes; 8 - local abyssal fracture; 9 - other fractures; 10 - geological boundaries; 11 - notional boundaries of greenstone belts. 
in favour of this assumption. The formation process of these megastructures from the point of view of abyssal magmatic plumes is considered in our previous publications (Isakov, 2017). It should only be noted that the structural-geological body of the above mentioned megastructures is determined by granitegneiss domes with the development (in some structures) in their central parts with large granitoid batholites of complex internal structure and wide range of material composition, surrounded by synclinal- and graben-like trough structures composed of igneoussedimentary formations metamorphosed in the conditions of greenschist and amphibolite facies of regional metamorphism. The analysis of reconstruction of the sequence of geological processes resulting in the formation of these interrelated structures allows us to assume there was a series of stages in the formation of pegmatite fields, which can be divided into two main periods. The first period was associated with ultrametamorphic processes and led to the formation of ceramic pegmatites in ancient granite-gneiss dome structures with the formation of large areas, mostly of
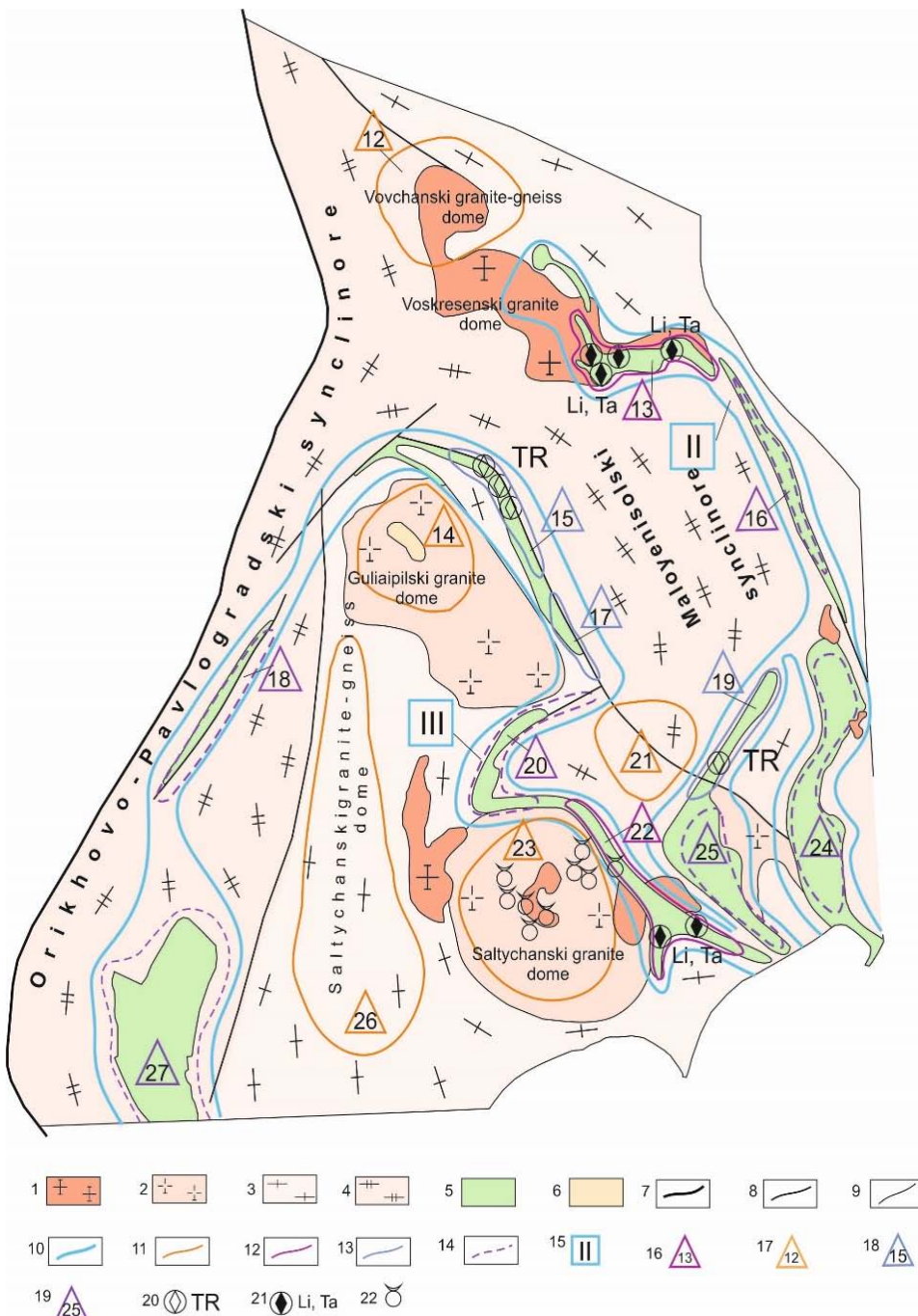

Fig. 3 Geological map of Western Pryazovia pegmatite region. isometric fields; while the second period of pegmatite formation is clearly associated with the process of forming granite intrusions and batholiths- pegmatites of this period are mostly associated with narrow trough structures developed around granite batholiths and granite-gneiss domes, and they could be formed in several stages.

The main factors influencing the formation and composition of pegmatites of the Ukrainian Shield. Based on the above considerations, we look at characteristics of four pegmatite regions (Volynska, Ingulska, Middle Prydniprovia and Western Pryazovia megastructures) presented by pegmatites of different origin and petrological and mineral composition and occurring in different structural and tectonic conditions, having different ages of formation, which allows us to make a full classification scheme of the pegmatites of the Ukrainian Shield.

Western Pryazovia megastructure. The gradual interrelated development of the megastructure (Isakov, 2011, Isakov, 2012) respectively affected the formation of its tectonic structures of a higher order,

1 - two-feldspar granites of Dobropilski, Saltychanski and Yanvarski complexes; 2 - plagiogranites, tonalites of Shevchenkivski complex; 3 - metamorphic Western Pryazovia series and ultrametamorphic Novopavlivski complex of dome structures; 4 - metamorphic formations (Vovchanska and Dragunska), Central Pryazovia series and ultrametamorphic complexes (Remivski and Tokmatski) of sutural zones; 5 - metamorphized igneous-terrigenous complexes (Osypenkivska series and Novogurivska, Ternuvatska, Kosivtsivska formations) of trough structures of greenstone type; 6 - terrigenous complexes of fault-line superimposed structure (Guliapilska suite); 7 - local abyssal fractures; 8 - other fractures; 9 - geological boundaries; $10-14-$ notional boundaries: 10 - of pegmatite belts; 11 - of ceramic pegmatite fields; 12 - of rare metal pegmatite fields; 13 - of rare earth pegmatite fields; 14 - of pegmatite fields of unspecified specialization (presumably rare metal, rare earth specialization); 15 - pegmatite belts: II - Shevchenkivsko-Vislynski; III - Sorokynsko-Gaichurski; 16 - ceramic pegmatite fields: 16 - KamenskoVovchanske; 18 - Guliaipilske; 25 - Temriuk-Korsakske; 27 -Yeliseivske; 8 - Tokmachanske; 17 -rare metal pegmatite fields: 17 - Shevchenkivske-Fedorivske, 26 - Sorokynske; 18 - rare earth pegmatite fields; 19 - Gaichurske, 21 - Kuibyshevske, 23 - Vislynske; 19 - specified pegmatite fields and fields of unspecified rare metal, rare earth specialization: $17 \mathrm{a}$ - Vovchanske, 20 - Pavlilvske, 22 - Chystopilske, 24 - Dragunske, 29 - Molochanske; 20 - deposits and ore occurrences of rare earth associated with pegmatites: 5 - Gaichurska group, 6 Kuibyshevske, 7 - Mogyla Visla; 21 - deposits and ore occurrences of rare metals associated with pegmatites: 1 - Voskresentki, 2 - Voskresentki-2, 3 - Shevchenkivske, 4 - Mokroialynski, 9 - Kruta Balka, 10 - Golubi Skeli; 22 - deposits and ore occurrences of ceramic raw materials associated with pegmatites: 8 - deposit group (Balka Velykogo Taboru, Dalnia Kamchatka, Balka Glyboka, Dolynske, Yelisiivske and others.) 
the granitoid formations and the pegmatites associated with them. Due to the influence of the deep processes caused by the action of the magmatic plume, the Ovchanskiy and Saltychansky middle granitoidgneiss domes were formed; and as compensatory structures around them, the Oryhivsky-Pavlogradsky and Maloenysolsky synclinores are represented by a narrow isocline folded structure (Fig. 2). Granitegneiss domes are composed by the formations of the Western Priazovian series of the early Archaean and heterogeneous granite rock masses - Saltychansky and Gulyaypilsky represented by plagiogranites, tonalites, diorites, occasionally gabbro of the Shevchenkivsky and Obotoknovsky complexes of the late Archean age (2.8 billion years). The syncline structures, united into a single zone in the central part, are composed of the Vovchanska, Dragunska, and
Novopavlivska formations of crystalline schist and gneisses of different composition of the amphibolite stage of metamorphism, and the Central Pryazovian series of high-alumina formations, whose age varies from the early Archaean to the Early Proterozoic, which may explain the complex structure of the synclinores. Greenstone structures are located in the junction zones of synclinores and dome structures and form two sub-parallel segmental semicircular greenstone belts - the Shevchenkivsko-Berestovsky and the Sorokinsky-Gaichursky. The former consists of the following trough structures: Shevchenkivska, Fedorivska, Vovchanska and Dibrovska surrounded by the Vovchansky dome; and the Pavlivska and Berestovska structures within the Maloyansilsky synclinoria. The Sorokinsko-Gaichursky greenstone belt is composed of the Sorokinska and Dragunska trough
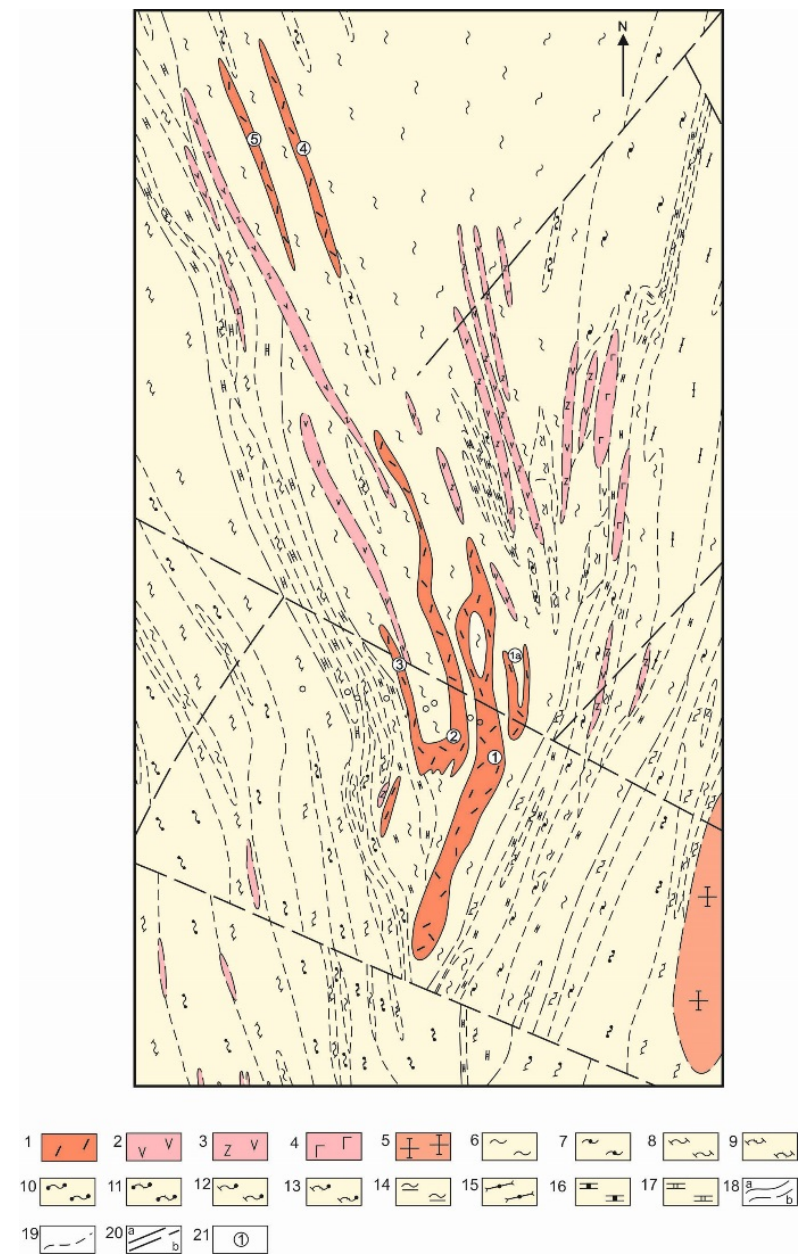

Fig. 4 Geological map of Shevchenkivski node of rare metal pegmatites:

1-4 - pegmatites: 1 - albite-spodumene, albite-petalite-spodumene; 2 - albite; 3 - albite-microcline; 4 - microcline and microclineoligoclase; 5 - muscovite-biotite, amphibole-muscovite-biotite fine- and medium-grained, muscovite-biotite pegmatoid granites; 6-17 - Ternuvatska rock mass, crystal slates: 6 - biotite, 7 - amphibol-biotite, 8 - muscovite-biotite, 9 - sillimanite-muscovitebiotite, 10 - garnet-biotite, 11 - garnet- sillimanite-biotite, 12 - garnet-muscovite-biotite, 13 - sillimanite-garnet-muscovite-biotite, 14 - biotite tourmalin bearing, 15 - quartz-sericitic; 16 - epidote- and quartz bearing scarified calciphyre; 17 - quartz-garnetepidote-pyroxene calc-silicate hornfels; 18 - boundaries between subsections of different age: a - determined, 6 - anticipated; 19 - boundaries between lithological types of rocks; 20 - fractures: a - determined, $\sigma$ - anticipated; 21 - numbers of pegmatite bodies. 
structures surrounded by the Saltychansky granite dome and Kuibyshevska, Gaichurska, Kosivtsivska ones-surrounded by the Guliaipilsky granite dome. They are close to the composition of volcanogenicterrigenous rocks of the Osipenkivska series and the Kosivtsivska and Ternuovatsky formations of the Meso-Neoarchean era, metamorphized in conditions from the greenstone to the amphibolite facies of the regional metamorphism. Along these structures are developed granite masses of the Yanvarsky and Saltychansky complexes, whose age according to various estimates is 2.6-2.2 billion years. The structures that form these green-stone belts are the main reservoir for rare-metal and rare-earth pegmatites (Fig. 3).

Concerning the pegmatite formation stages within the Western Pryazovia megastructure, the first stage of pegmatite formation is ultrametamorphism that developed intensely in the final stage of formation of the dome-synclinore structure of Western Pryazovia (Remivski ultrametamorphism). In this period pegmatites were formed as neosoms in the process of partial melting of rock complex of both the ceramic pegmatite field around it and within autochtonous granite massifs.

Pegmatite formation of the second stage is associated with the establishing of granite-gneiss domes and bedding of Shevchenkivski plagiogranite massifs. The establishment of allochtonous plagiogranite massifs of this complex was accompanied by bedding of the bulk of ceramic pegmatites with wide fields of formation (Yeliseivske, Temriuk-Korsakske, Vovchan- ske and Guliaipilske) located both in granite massifs and in rock complexes of the Western Pryazovian, and sometimes in Vovchanska and Dragunska rock masses.

The establishment of multi-stage intrusives of two-feldspar granites of Yanvarski, Dobropilski and Saltychanski complexes (the third stage) was accompanied by intrusion and penetration of a significant mass of pegmatite matter in the weakened zones of trough structures of greenstone belts with the formation of pegmatites of different types (in particular, rare metal and rare earth) depending on the time, depth of their intrusion and specialization of the massifs. Resulting from these processes there formed the fields of rare metal and rare earth pegmatites: Shevchenkivske, Fedorivske, Vovchanske, Sorokynske, Gaichurske and others, in their turn forming the SorokynskoGaichurski and Shevshenkivsko-Berestivski pegmatite belts. They are associated with such well-known deposits of rare metal pegmatites as Shevchenkivske (Isakov, 2013) (Fig. 4) and Kruta Balka (Rozanov, 1979) (Fig. 5).

Middle Prydniprovia megastructure is attributed to the category of specific lower Pre-Cambrian geostructural elements of the Earth crust - granite-greenstone areas or folded-dome greenstone belts (Bobrov, 2002, Sivoronov, 1983, Shcherbakov, 2005) associated with large pegmatite provinces in other shields -Yilgarn in Australia, Winnipeg-Nipigon Abitibi in North America and others. The megablock is characterized by relative time sequence of change of geo-

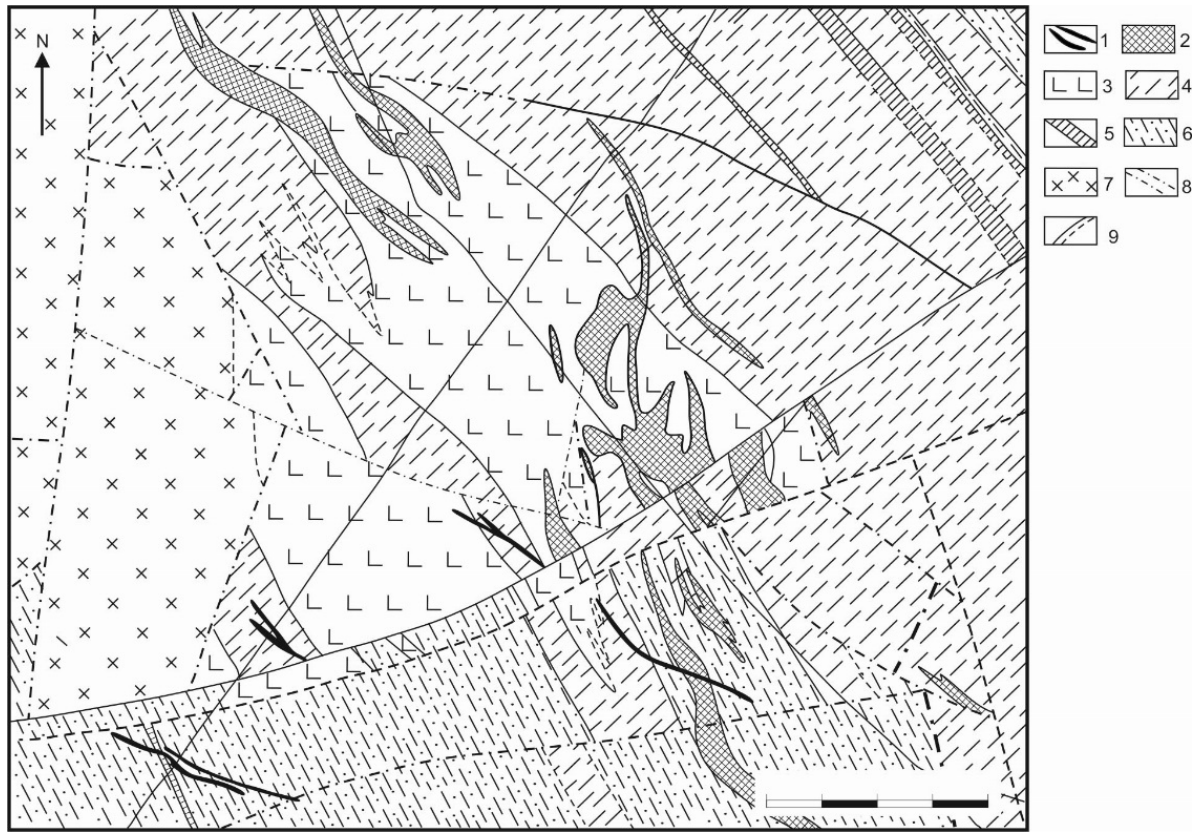

Fig. 5 Schematic geological map of Kruta Balka pegmatite node [14]:

1 -quartz veins; 2 - pegmatite bodies; 3 -metaultrabasite; 4 - slightly metamorphized biotite, amphibolic and other types of slates; 5 -quartzites; 6 - metagravelite and metaconglomerate; 7 -diorite-granodiorite; 8 -fractures; 9 -geological contours. 
logical conditions similar to the above provinces in the formation of rock complexes as well as their effect on the development and establishment of pegmatite fields.

The megastructure includes the following closely interconnected structural units (Fig. 6): 1) Saksagansky, Zaporizky, Pyatihatsky, Demurinsky, Slavgorodsky and other granite-gneiss and migmatite-gneiss domes made of supracrustal formations of the Aulska series and Dnipropetrovsk and Slavgorod plagiogranite-migmatite and endebit-charnokytoid complexes; 2) the Krivorizko-Kremenchutsky, Bazavlutsky and Konksko-Belozersky green-stone belts are composed by the Vysokopilsky, Chortomlitsky, Sofievsky, Verkhovtsy, Sursky, Zhovtovodsky and other green-stone downfolds composed of apo-volcanogenic formations of the Konkska series and apo-sedimentary formations of the Bilozerska series; 3) plagiogranite rock masses of the Saksagansky and Sursky complexes connected with green-stone structures; 4) multi-phase granite massifs: Demurinsky, Mokromoskovsky, Tokivsky, Orilsky and others related to green-stone structures. By structural form and history of its formation, the Middle Pridniprovian megastructure is the plume structure of the Ukrainian Shield (Isakov, 2017).

The lower age limit of the Konkska series is de-

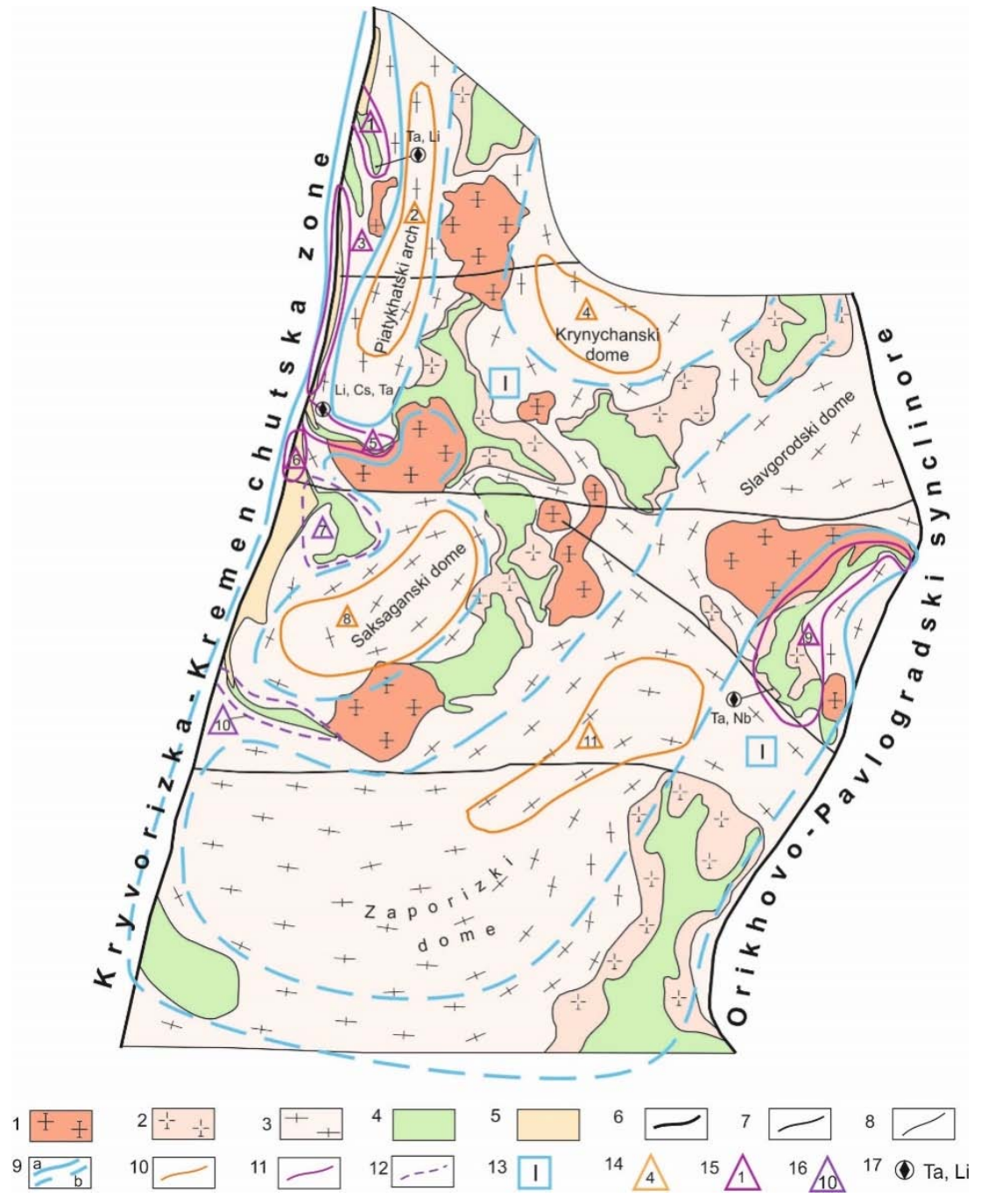

Fig. 6 Schematic geological-structural map of Middle Prydniprovia pegmatite region

1 - two-feldspar granites of Demurski, Tokivski, Mokromoskovski complexes; 2 - plagiogranites, tonalites of Surski and Saksaganski complexes; 3 - metamorphic series (Aulska) and ultrametamorphic complexes (Slavgorodski and Dnipropetrovski) of dome structures; 4 - metamorphized igneous-terrigenous complexes of trough structures of greenstone type (Konkska and Bilozerska series); 5 - terrigenous complexes of fault-line superimposed structures (Kryvorizka series); 6 - abyssal regional fractures; 7 - fractures; 8 - geological boundaries; 9 - notional boundaries of pegmatite belts that encompass: a - established pegmatite fields; $\sigma$ - conditionally established and anticipated pegmatite fields; $10-14$ - notional boundaries of pegmatite fields: 10 - ceramic, 11 - rare metal, 12 - unspecified (presumably of rare metal and rare earth) specialization; 13 - pegmatite belts: I - Komendantivsko-Zhovtovodsko-Mokromoskovski; 14 - ceramic pegmatite fields: 2 - Piatyhatske, 4 - Krynychanske, 8 Bazavlutske, 11 - Tokmatske; 15 - rare metal pegmatite fields: 1 - Komendantivske, 3 - Mykolaivke, 5 - Zhovtovodske, 6 Gannivske; 16 - pegmatite fields of specified and unspecified (presumably) of rare metal, rare earth specialization: 7 - Ternivske, 10 - Vysokopilske; 17 - mineral occurrence of rare metals associated with pegmatites. 
termined by the age of zirconium from the metavolcanites of the Surska suite- 3177 Ma upper age limit - by the age of zirconium from plagiogranites of the Sursky complex - up to 2960 Ma. The lower age limit of the Bilozerska series is determined by zirconium from meta-keratophyres - $3000 \mathrm{Ma}$. The upper age limit of the entire green-stone rock mass is determined by the age of the youngest granite of the Demurinsky and the Mokromoskovsky complexes that transect it - 2850-2700 Ma (Shcherbak, 2005).

The fields of ceramic pegmatites located immediately within granite-gneiss domes indicate the first stage of formation of pegmatites in the period of ultrametamorphism of dome structures of rock complexes. In outcrops there is discovered close or immediate location of these pegmatites in migmatites and granit-

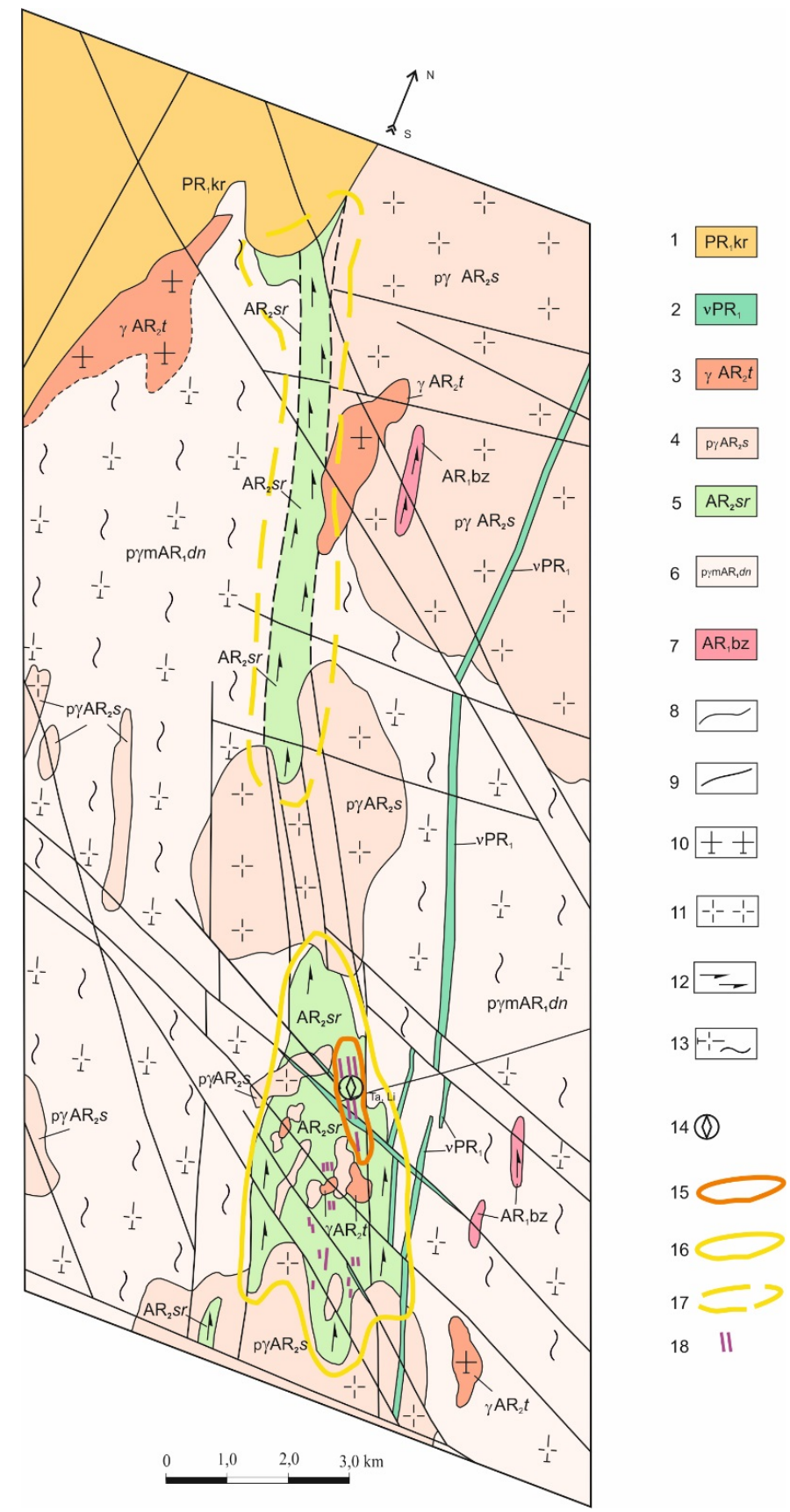

Fig. 7 Geological map of the Komendantivska greenstone structure and location of the same-name pegmatite field, node and ore occurrence within in:

1 - formation of the Kryvorizka series; 2 - diabase dikes; 3 -granites of the Tokivski complex; 4 - plagiogranites of the Surski complex; 5-gabbro-diabase6-8 - formation of Surska suite: 6 - amphibolites; 7 - amphibole, amphibole-biotite crystal slates; 8 - talktremolite-serpentine slates; 9 - plagiomigmatites of the Dnipropetrovsk complex; 10 - formation of the Bazavlutska rock mass; 11 geological boundaries; 12 - fractures; 13 - Komendantivski node of rare metal pegmatites; $14 \mathrm{a}$ - Komendantivske field of rare metal pegmatites; 146 - anticipated field of rare metal pegmatites; 15 - pegmatite veins; 16 - Komendantivski ore occurrence of tantalum and lithium. 


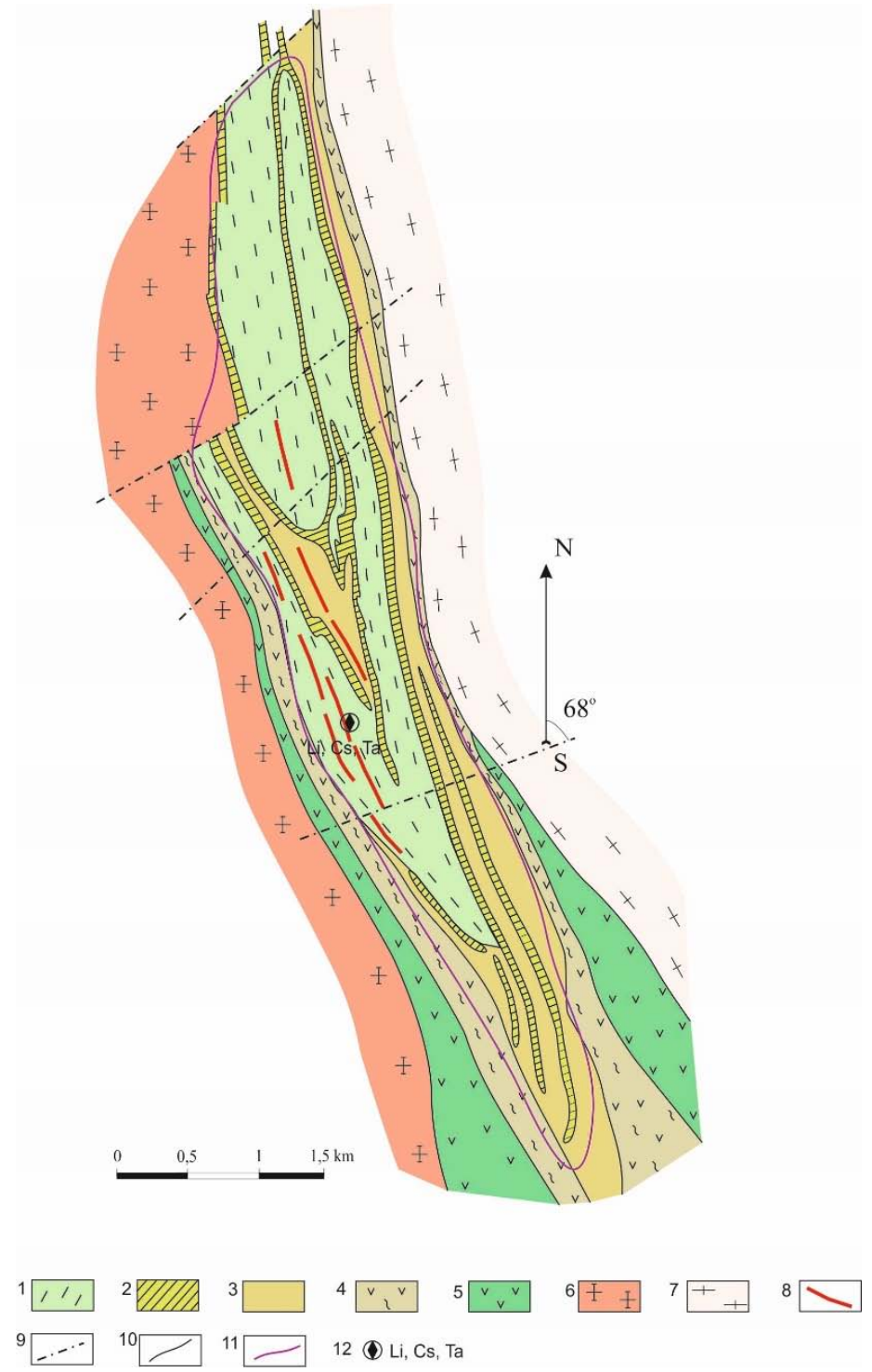

Fig. 8. Geological map of the Zhovtianski pegmatite field:

1-4 - formation of Kryvorizka series: 1 - dolomite, quartz-biotite rock mass with graphite of microschist, diopside quartzites, actinolite shales; 2 - magnetite-hematite jaspilite, magnetite-hematite hornfels; 3 - rock mass of amphibole, mice, mice-amphibole shales; 4 - sericitic quartzite with fuchsite, amphibole-biotite gneiss; 5 - amphibolites of Konkska series; 6 - Demurivski granites; 6 Dnipropetrovsk plagiomigmatites; 8 - pegmatites; 9 - fractures; 10 - geological boundaries; 11 - notional boundaries of Zhovtianski field of rare metal pegmatites; 12 - Zhovtianski ore occurrence of rare metals.

oid formations of the Dnipropetrovsk complex, which indicates their genetic connection with this complex, as well as their ultrametamorphic nature.

In the second stage within granite-gneiss domes there formed large fields of ceramic pegmatites as derivatives of buried plagiogranite pegmatites (the most well-known are the Bazavlutske pegmatite fields located in the central part of the Saksaganski dome).

Pegmatite formation of the third period is associated with the establishment of greenstone structures and the Kryvorizko-Kremenchutska structural-facial areas. Pegmatite formation is associated with the formation of multi-stage intrusives of two-feldspar granite complexes (Demurski, Mokromoskivski, Tokivski, Orilski massifs) and was accompanied by the intrusion and inflow of a considerable mass of pegmatite matter into weakened areas of trough greenstone structures with the formation of pegmatites of different types, in particular rare metal and rare earth depending on the time, the depth of its separation and specialization of the massifs themselves. The absence of pegmatite fields within the majority of greenstone structures is explained by only one reason - insignificant erosional truncation of these structures. The fields of rare earth pegmatites are discovered within the Kryvorizko-Kremenchutska structural-facial ar- 
eas where they form the Petrovske and Mykolaivske long fields. Pegmatite fields of rare metal specialization (Zhovtovodske, Komendantivske, Mokromoskovske) are traditionally "attached" to separate greenstone trough structures and their aureole. Grouping with fields of rare earth specialization, they form the long (up to several hundred kilometers) Komendantivsko-Zhovtovodsko-Morkomoskovski pegmatite belt. Here are manifested such ore occurrences of rare metals as Komendantivske (Fig.7) and Zhovtovodske (Fig.8) (Isakov, 2013). The fields are formed by the following types of pegmatites: microcline, oligoclasemicrocline, oligoclase; albite rare metal: 1) without lithium minerals; 2) with lithium minerals.
Ingulska and Volynska megastructures. The key structural-geological position in the structure of these megablocks is taken by thick granitoid batholites of complex internal structure and wide range of composition. Analysis of the restored sequence of geological processes causing their formation gives an opportunity to regard these megablocks based on the hypothesis of abyssal convection current and magmatic plumes (Isakov, 2017).

In the formation of Ingulska megastructure the following tightly connected structural unites are involved: 1) the Novoukrainski and Korsun-Novomyrgorodski plutons (magmatic dome); 2) the system of synclinore structures (Bratska and Pryingulska),

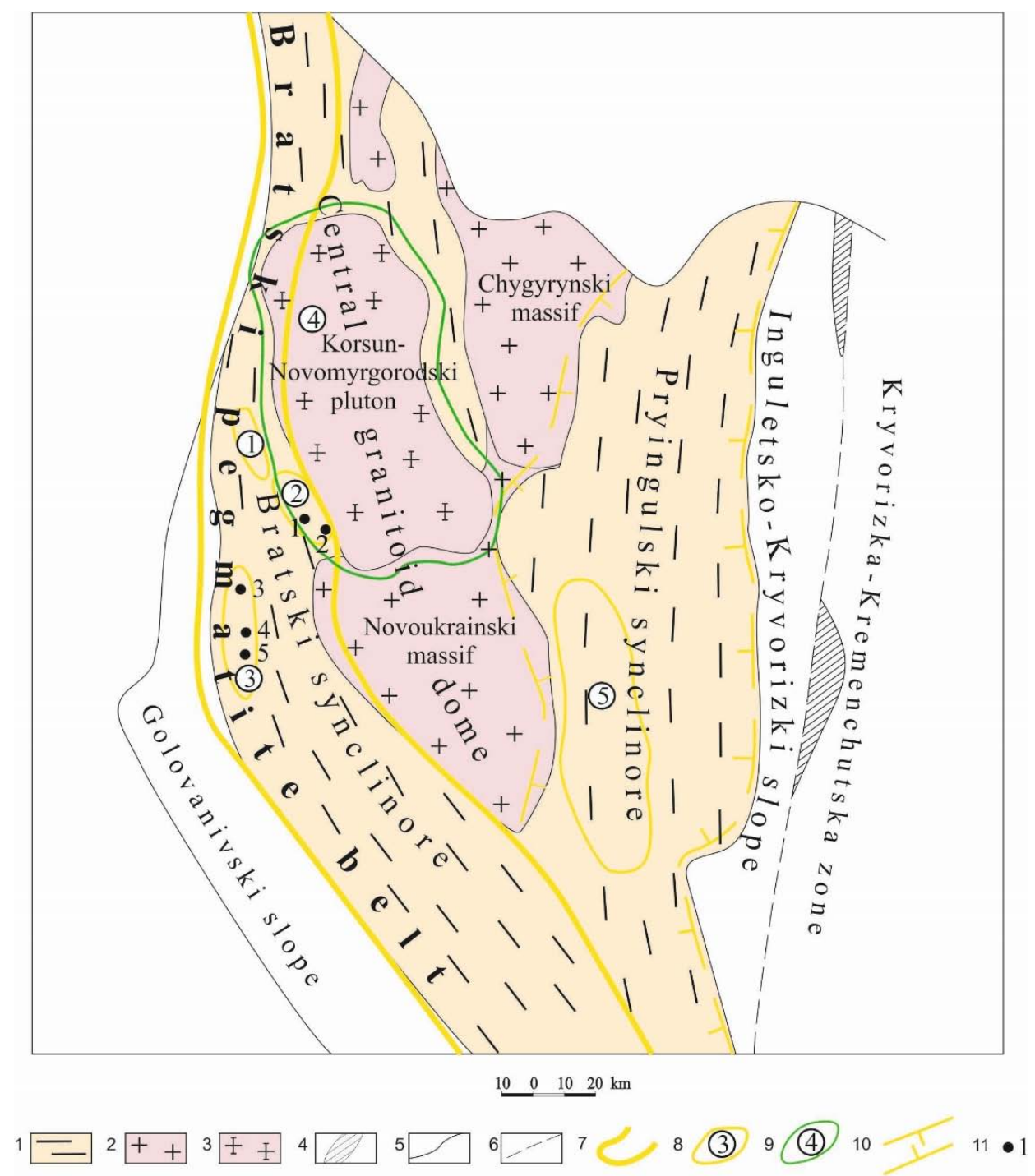

Fig. 9 Contour map of Ingulski pegmatite region

1. Small-dome structure of the Bratski and Pryingulski synclinore formed by rock formations of the Ingulo-Inguletska series and granites of the Kirovograd complex. 2. Intrusive formations of the Novoukrainski complex. 3. Intrusive formations of the KorsunNovomyrgorodski complex. 4. Metaterrigenous formations of the Kryvorika series. 5. Geological boundaries. 6. Fractures. 7. Notional contours of the Bratski pegmatite belt. 8. Notional contours of rare metal pegmatite fields: 1-Vys, 2-Mostove, 3-Lypniazke, 5-Kirovogradske. 9. Notional contour of anticipated contour of development of pegmatite fields of chamber pegmatites: 4-notionally contoured Korsun-Novomyrgorodske field. 10. Notional contour of anticipated development of rare metal pegmatite fields. 11. Ore occurrences and deposits of rare metal pegmatites: 1-Mostove, 2-Polohivske, 3-Lypniazke, 4-Stankuvatske, 5-Nadia. 
their fringing; 3) Golovanivska and Kryvorizko-Kremenchutska inclining (suture, according to (Isakov, 2017)) zones fringing the megablock (Fig.9).

Within the Bolynska megastructure tightly connected structural units are singled out : 1) Gorognytsko-Korostenski ultrametamorphic magmatic dome (Gorodnytsko-Yemilchynski granite-migmatite dome and Korostenski pluton); 2) the system of synclinore structures forming the Pivdennovolynski synclinore (Teterivski dip, after V.A. Riabenko, or the Zhytomyrski synclinore, after V.M. Klochkov); 3) Ovrutska graben-synclinal with its Bilokorovytski and Vilchanski branches (Fig.10).
The process of granite and pegmatite formation as the main generator of pegmatite matter within megablocks was rather similar and realized in at least three stages.

The first stage is the formation of proper ceramic pegmatites of quartz-oligoclase microcline, quartzoligoclase, quartz-microcline composition among old ultrametamorphic rock complexes of dome structures (Sheremetivski and Inguletski complexes).

The second stage. The first sub-stage is bedding of granites of Kirovogradski and Zhytomyrski complexes presented by biotite, garnet-biotite, muscovite-biotite two-feldspar granites, aplite-pegmatoid

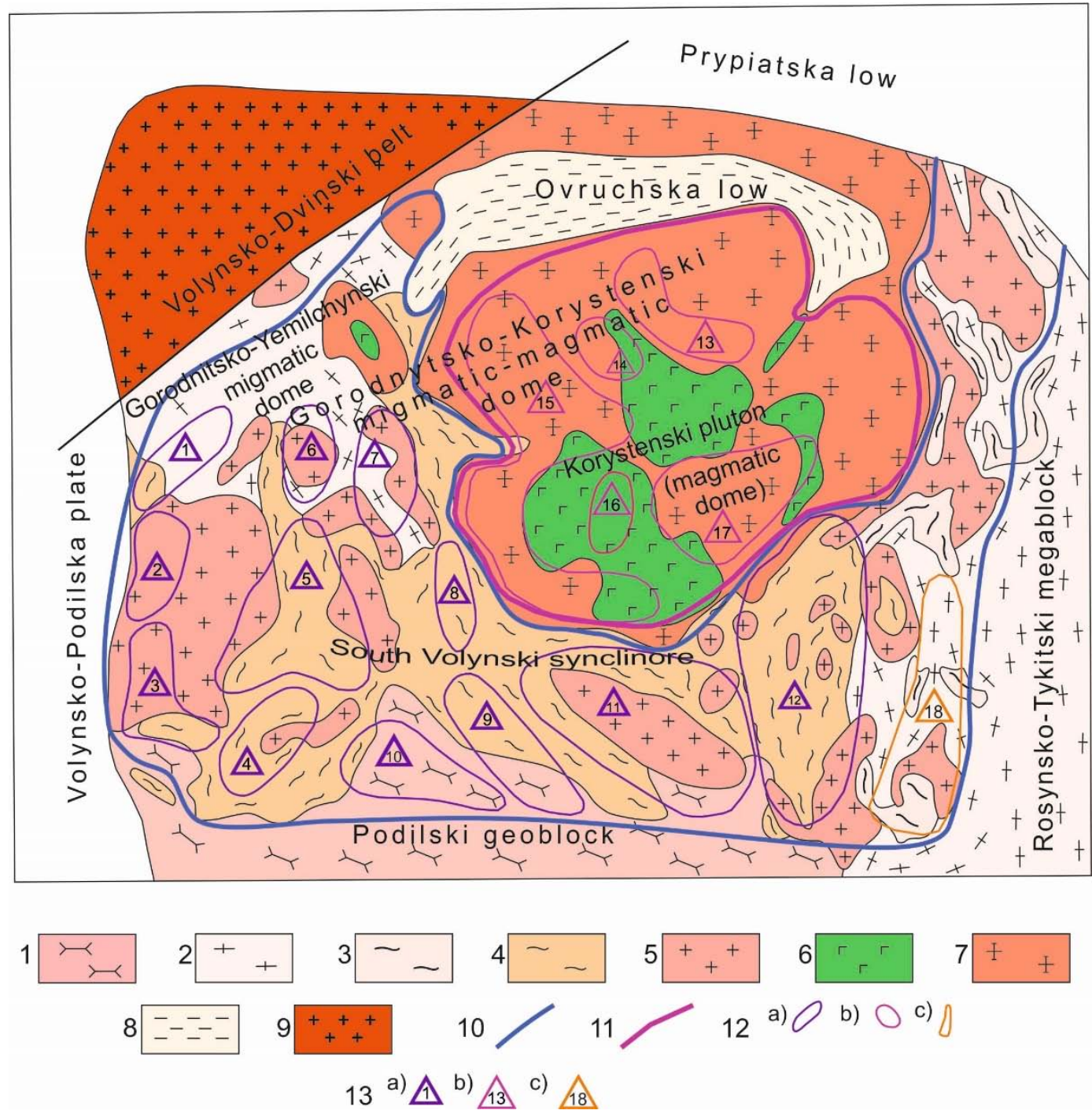

Fig. 10 Contour map of Volynski pegmatite region.

1 - migmatites and granites of the Pobuzki complex; 2 - migmatites of the Sheremetivski and Tetiivski complexes; 3 rock complexes of the Rosynsko-Tikytska series; 4 - rock of Teterivska series complex; 5 - granites of Zhytomyrski complex; intrusive formations of complex ( 6 - gabbro, 7 - granite); 8 - rock of Ovrutska series complex; 9 - granites of Perzhanski complex; 10 - notional contour of Volynski pegmatite belt; 11 - notional contour of Korostanski stockwork of chamber pegmatites; 12 - notional boundaries of pegmatite fields: $\mathrm{a}$ - rare metal and rare earth; $\mathrm{b}$ - chamber; $\mathrm{c}$ - ceramic; 13 - Pegmatite fields: a - rare metal pegmatites: 1 - Gorodnitske; 2 - Koretske; 3 - Shepytivske; 4 - Polonno-Baranivske; 5 - Novograd-Volynske; 6 - Serbivske; 7 - Barashenske; 8 - Tesnivske; 9 - Kodynynske; 10 - Berdychivske; 11 - Zhytomyrske; 12 - Kocherivske; $b$ chamber pegmatites: 13 - Ignatpilske; 14 - Behinske; 15 - Volodarsko-Volynske; 16 - Irshanske; 17 - Malynske; c - ceramic pegmatites: 18 - Yablunovsko-Volodymyrske. 
granites, aplites and pegmatites that form a range of massifs within synclinore structures, including rather large ones. Their age is estimated at $2000 \mathrm{mln}$ years and older (Shcherbak,2005). These granite complexes are associated with the majority of ceramic, rare earth and rare metal pegmatites. The absence or low occurrence of rare metal pegmatites within the Volynska megastructure can be explained only by its insignificant erosive level. This didn't allow us to sort out these pegmatite fields, and in the given scheme (Fig.10) all of them are highlighted as potentially rare metal fields.
The second sub-stage is a further formation of central magmatic dome and bedding of two large massifs (plutons) of complex structural and material composition within the Ingulski megablock: Novoukrainski and Chygyrynski plutons composed mainly by granites of biotite and granite-biotite with bodies of gabbronorite, norites, monzodiorite, monzonite, quartz syenite of frequent occurrence. The age of rock formations of the Novoukrainski complex is estimated at $2030-2000 \mathrm{Ma}$ (Shcherbak, 2005), that is the granites of the Kirovogradski complex and associated granites
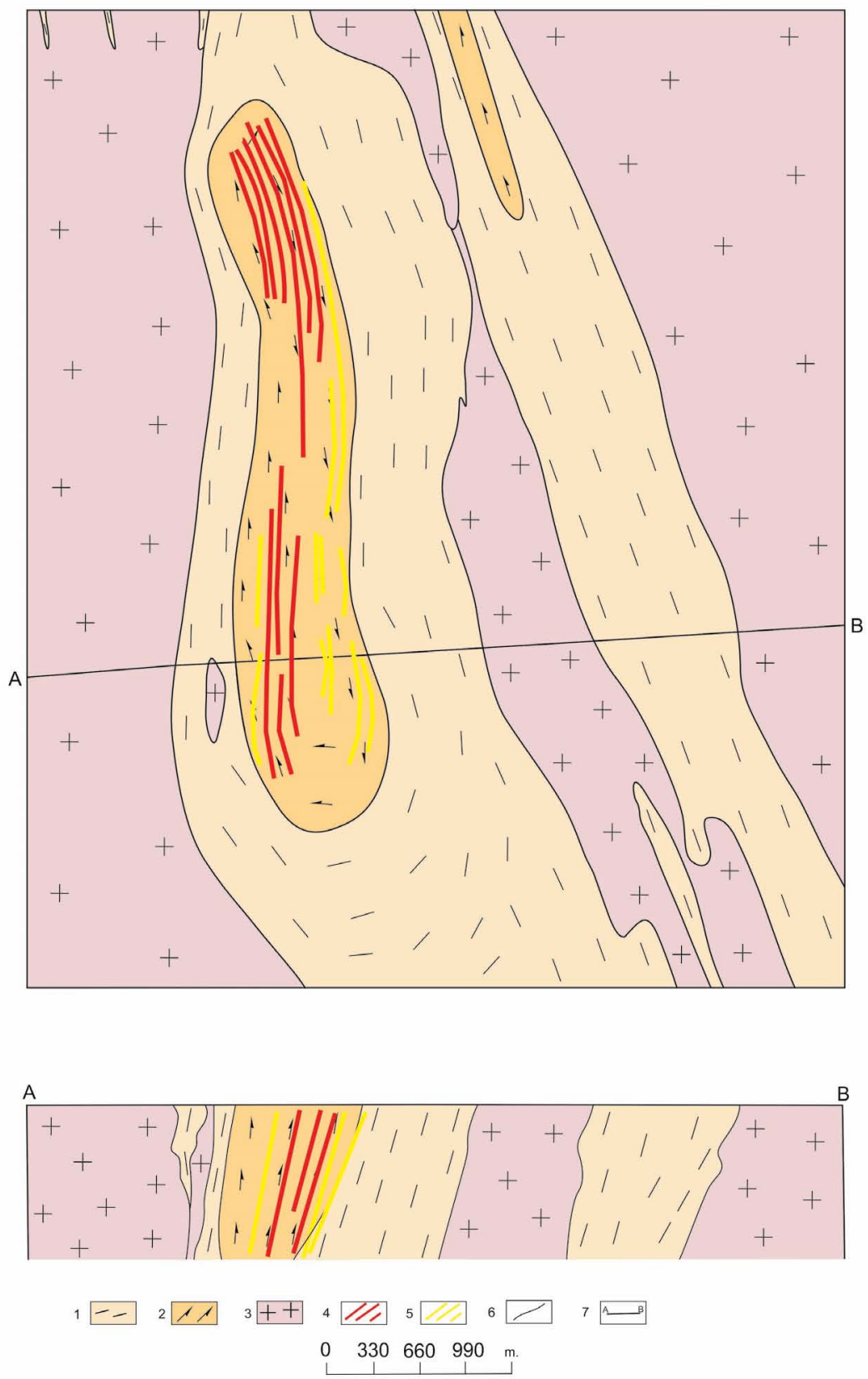

Fig.11 Schematic formation of Stankuvatski and Nadia nodes of rare metal pegmatites.

1 - gneiss and shale of biotite, garnet-biotite, cordierite-biotite, graphite-cordierite-biotite, amphibol-biotite, pyroxene-biotite nature; 2 - amphibolites; 3 - biotite granites with garnet and cordierite; 4 - pegmatites: petalite-spodumene, albite rare metal; 5 - quartz twofeldspar ceramic pegmatites; 6 - geological boundaries; 7 - cross-section line. 
and aplites are derivates of a common magmatic environment that were separated at the early abyssal stage of its establishment, which after some period of time were moved and formed the Novoukrainski and associate massifs. Thus, pegmatites within the Ingulska megastructure (rare metal ones in particular) associated with both the Kirovogradski and Novoukrainski granite complexes have common genetic nature and are divided by the formation stages. This complex is associated with pegmatites of the Polohivske deposit of petalite pegmatites, the Lipniazhska group of de- posits (Stankuvatske, Nadia, Lipniazhske) (Fig.11) and Mostova group of deposits (Mostove-3, in particular) (Fig. 12) of rare metal pegmatites (Voznyak, 2001, Yeryomenko, 1996, Ivanov, 2002).

The third stage is the final stage of formation of the central magmatic dome - bedding of the KorsunNovomyrgorodski and Korostenski plutons of complex structural and material composition formed by mainly granites of rapakivia and gabbro-anorthosite. Granites of these plutons are also associated with pegmatites, chamber ones in particular (known Volynska

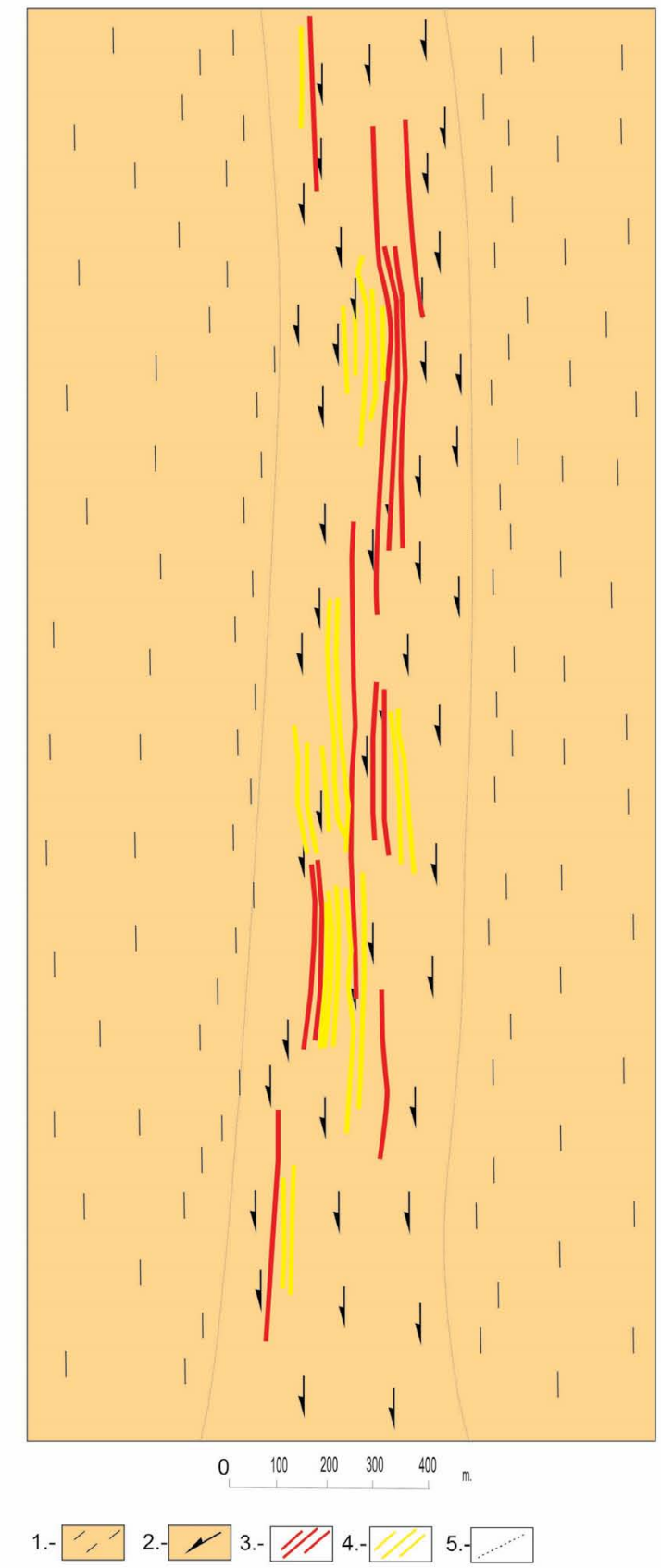

Fig.12 Scheme of formation of Mostove-3 pegmatite node

1 - Biotite-gneiss; 2 - Biotite gneiss with silimonite, cordierite, muscovite, garnet; 3 - Quartz-albite rare metal pegmatites; 4 - Quartz two-feldspar pegmatites. 
group of deposits of chamber pegmatites (Mineralogy, 1973). Their absence or insignificant occurrence within the Ingulska megastructure can be explained by the significant erosive level of the massif, which resulted in the destruction of the majority of chamber pegmatites.

Thus, within the Ingulska and Volynska megastructures we observe such pegmatites that both in common and separately form independent pegmatite fields: proper ceramic, rare earth and rare metal, as well as chamber pegmatites. The time sequence of the formation of the indicated types of pegmatites appears as follows: ceramic pegmatites $\rightarrow$ rare earth and accompanying barren pegmatites $\rightarrow$ rare metal and accompanying barren pegmatites $\rightarrow$ chamber pegmatites

Systematization of pegmatites of the Ukrainian Shield. Pegmatites are not original or unique either for the Ukrainian Shield or for other Early PreCambrian structures of the world. This is explained, first of all, by geological and structural conditions of this period that were favourable for the development of different types of granitoid formations which, in their turn, were the main generators of pegmatite matter not only in early but also in later periods of earth crust development. Different depth of origin and establishment of magmatic environments and variety of forms of granitoid manifestations in their turn gave origin to the variety of forms, composition, geochemistry, metallogenic specialization of pegmatites. Their form, composition, geochemical and metallogenic specialization were also greatly influenced by Pt-condition of the surrounding environment, composition of the hosted rocks, tectonic conditions and a range of other factors occurring in the process of their establishment and formation. All the above conditioned significant differences of pegmatites in composition of both basic rock-forming mineral and in internal structural and texture characteristics, as well as in microelement composition and the presence of a large range of accessory and rare minerals that reach percentage composition in pegmatites or become rockforming. This characteristic of formation and internal structure, as well as the composition of pegmatites resulted in the appearance of different, often opposite, working hypotheses about their genesis and formation (Ginzburg, 1979, Kuz'menko, 1978, Nikanorov, 1979, Petrov, 1975, Shavlo, 1984, Shmakin, 1987 and oth.). For instance, O. Fersman and K. Vlasov considered pegmatites to be the result of the crystallization process of residual magmatic melting enriched by volatile components; while D. Korzhynski and V. Nikitin thought it to be the result of influence of post-magmatic melting on re-crystallization and replacement of magmatic genesis rocks. This, in its turn, caused a large number of classification systems and classifications developed by different authors in different years. The majority of these classifications are built on classification features - typomorphic, rock-forming and ore minerals, structural and textural characteristics of pegmatites, abyssal establishing, or economic value.

Sometimes classification systems are composed by a range of genetic and geological-structural features and conditions of pegmatite formation. The principles of their classification are acceptable with one provision: the desire of these authors to build the general holistic concept of singling out pegmatites by the primary characteristic (gradual change of depth or the level of regional metamorphism, processes of re-crystallization and replacement during metamorphism and metasomatosis, rare metal mineralogical and geochemical specialization etc) resulted in significant simplification of the process of formation and establishment of pegmatites of different associations, as well as in the loss of a range of important factors of this process. That is, the role of separate and, in the authors' opinion, major and only factors in the establishment of pegmatite associations is not so significant and in many cases exaggerated.

Without going deep into general critical analysis, for it is already presented in the above mentioned researchers and authors in (Isakov, 2006), on the basis of genetic and geological-structural factors of formation of pegmatites of the Ukrainian Shield, we will try to construct a general scheme that would reflect general regularities of pegmatite formation in early Pre-Cambrian structures and would reconstruct the general logical chain of abyssal processes of their formation (Table 1). It is based on the characteristic features of formation and development of pegmatite-generating environments and pegmatite-bearing structures, tectonic-structural characteristics of pegmatite-bearing areas during the process of their establishment, as well as the influence of external metamorphogenicmetasomatic processes on the already formed pegmatites.

By the development of pegmatite-generating environments we single out:

- three genetic groups of pegmatites: ultrametamorphogenic, magmatogenic and metamorphogenicmetasomatic;

- six genetic sub-groups of pegmatites: migmatite; autochtonous granite massifs; metamorphogenic and metasomatically replaced and formed pegmatites; multi-phase intrusive granite massifs; multi-phase in- 
Table 1. Classification of pegmatites of Pre-Cambrian shields (on the example of the Ukrainian Shield)

\begin{tabular}{|c|c|c|c|c|c|c|}
\hline \multicolumn{3}{|c|}{ Groups of pegmatites } & \multirow{3}{*}{$\begin{array}{c}\text { Genetic } \\
\text { subgroups of } \\
\text { pegmatites }\end{array}$} & \multirow{3}{*}{$\begin{array}{l}\text { Associations } \\
\text { (formations) of } \\
\text { pegmatites }\end{array}$} & \multicolumn{2}{|c|}{ Types of pegmatites } \\
\hline \multirow{2}{*}{$\begin{array}{l}\text { Ge- } \\
\text { netic }\end{array}$} & \multicolumn{2}{|c|}{ Geological-structural } & & & \multirow{2}{*}{$\begin{array}{l}\text { Mineralogical (by ore- } \\
\text { formation minerals) }\end{array}$} & \multirow{2}{*}{ Geochemical-metallogenic } \\
\hline & & oups & & & & \\
\hline \multirow{9}{*}{ 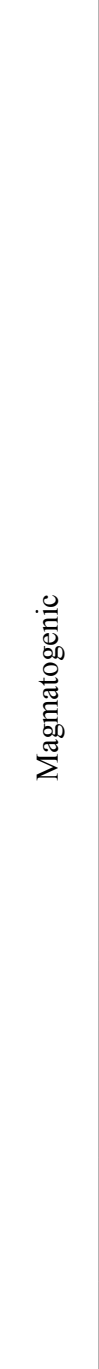 } & \multirow{9}{*}{ 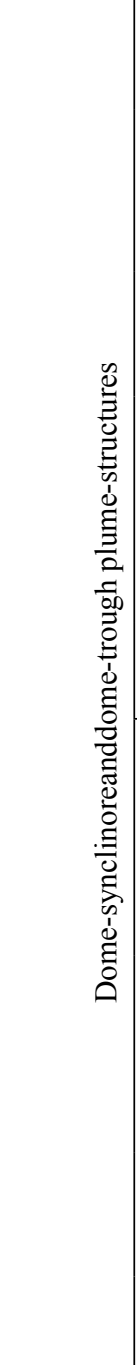 } & \multirow{5}{*}{ 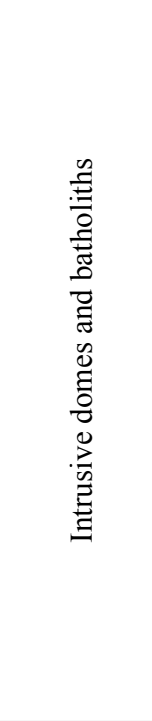 } & \multirow{3}{*}{$\begin{array}{l}\text { Multi-phase } \\
\text { granite batho- } \\
\text { liths }\end{array}$} & $\begin{array}{c}\text { Miarolitic and } \\
\text { chamber pegmatites }\end{array}$ & \multicolumn{2}{|c|}{$\begin{array}{l}\text { By different classifications offered by M.P.Yermakov } \\
\text { (1957) and Ye.K.Lazarenko, V.I.Pavlyshyn (1973) }\end{array}$} \\
\hline & & & & $\begin{array}{l}\text { Rare-metal pegma- } \\
\text { tites }\end{array}$ & $\begin{array}{c}\text { Microcline } \\
\text { Microcline-albite } \\
\text { Microcline-albite and } \\
\text { spodumene }\end{array}$ & $\begin{array}{c}\text { Rare metal, ore specializa- } \\
\text { tion in } \mathrm{Li}, \mathrm{Rb}, \mathrm{Cs}, \mathrm{Ta}, \mathrm{Nb} \text {, } \\
\mathrm{Be}, \mathrm{Sn}\end{array}$ \\
\hline & & & & Ceramic pegmatites & $\begin{array}{l}\text { Microcline } \\
\text { Microcline-oligoclase }\end{array}$ & $\begin{array}{c}\text { Rare geochemical and } \\
\text { insignificant rare special- } \\
\text { ization in } \mathrm{Nb}\end{array}$ \\
\hline & & & 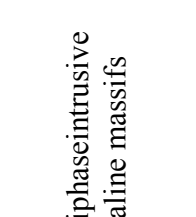 & $\begin{array}{l}\text { Thorium-rare-earth } \\
\text { pegmatites }\end{array}$ & $\begin{array}{l}\text { Albite-amazonite } \\
\text { Microcline } \\
\text { Albite-microcline } \\
\text { Albite-quartz } \\
\text { Oligoclase-microcline }\end{array}$ & $\begin{array}{l}\text { Rare earth, ore specializa- } \\
\text { tion in TR, Y, Ta, Nb, Zr }\end{array}$ \\
\hline & & & 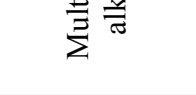 & Ceramic pegmatites & $\begin{array}{c}\text { Microcline } \\
\text { Microcline-oligoclase }\end{array}$ & Barren; \\
\hline & & 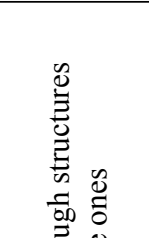 & & $\begin{array}{l}\text { Rare-metal pegma- } \\
\text { tites }\end{array}$ & $\begin{array}{l}\text { Microcline-spodumene } \\
\text { Albite-spodumene } \\
\text { Albite-petalite-spodumene } \\
\text { Albite } \\
\text { Albite-microcline } \\
\text { Microcline }\end{array}$ & $\begin{array}{c}\text { Rare metal and ore special- } \\
\text { ization in } \mathrm{Li}, \mathrm{Rb}, \mathrm{Cs}, \mathrm{Ta} \\
\mathrm{Nb}, \mathrm{Be}, \mathrm{Sn}\end{array}$ \\
\hline & & 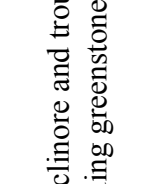 & $\begin{array}{l}\text { Mult1-phase } \\
\text { intrusive } \\
\text { granite mas- } \\
\text { sifs }\end{array}$ & $\begin{array}{c}\text { Rare-metal } \\
\text { muscovite-feldspar } \\
\text { pegmatites }\end{array}$ & $\begin{array}{l}\text { Muscovite-albite-micro- } \\
\text { cline-oligoclase } \\
\text { Muscovite-microcline-oli- } \\
\text { goclase }\end{array}$ & $\begin{array}{c}\text { Rare metal,geochemical and } \\
\text { ore specialization in } \mathrm{Ta}, \mathrm{Nb} \text {, } \\
\mathrm{Be}, \mathrm{Li}, \mathrm{Rb}, \mathrm{Cs}\end{array}$ \\
\hline & & 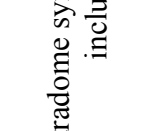 & & $\begin{array}{l}\text { Muscovite-feldspar } \\
\text { pegmatites }\end{array}$ & $\begin{array}{l}\text { Muscovite-microcline- } \\
\text { oligoclase } \\
\text { Muscovite-oligoclase }\end{array}$ & $\begin{array}{l}\text { Barren, possible (?) geo- } \\
\text { chemical specialization in } \\
\mathrm{Nb}, \mathrm{Zr}, \mathrm{TR}, \mathrm{U}\end{array}$ \\
\hline & & & & Ceramic pegmatites & $\begin{array}{c}\text { Microcline } \\
\text { Microcline-oligoclase }\end{array}$ & Ditto \\
\hline 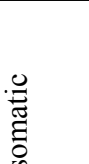 & 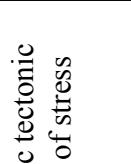 & & & $\begin{array}{l}\text { Beryl-muscovite } \\
\text { pegmatites }\end{array}$ & $\begin{array}{c}\text { Muscovite-albite-micro- } \\
\text { cline- } \\
\text { oligoclase } \\
\text { Muscovite-oligoclase }\end{array}$ & $\begin{array}{l}\text { Beryl-bearing, geochemical } \\
\text { specialization in } \mathrm{Be}, \mathrm{Nb}, \\
\mathrm{Zr}, \mathrm{TR}, \mathrm{U} \text {, ore specializa- } \\
\text { tion In Be }\end{array}$ \\
\hline . & 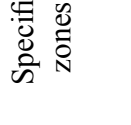 & & & $\begin{array}{l}\text { Muscovite } \\
\text { pegmatites }\end{array}$ & $\begin{array}{l}\text { Muscovite- microcline- } \\
\text { oligoclase } \\
\text { Muscovite-oligoclase }\end{array}$ & $\begin{array}{l}\text { Barren, possible (?) geo- } \\
\text { chemical specialization in } \\
\mathrm{Nb}, \mathrm{Zr}, \mathrm{TR}, \mathrm{U}\end{array}$ \\
\hline 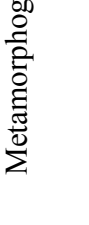 & 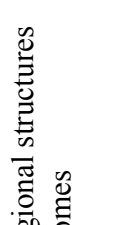 & & $\begin{array}{l}\text { Metamorpho- } \\
\text { genic-metaso- } \\
\text { matic replaced } \\
\text { and formed } \\
\text { pegmatites }\end{array}$ & Ceramic pegmatites & $\begin{array}{l}\text { Microcline } \\
\text { Microcline-oligoclase }\end{array}$ & $\begin{array}{l}\text { Barren, possible (?) geo- } \\
\text { chemical specialization in } \\
\mathrm{Nb}, \mathrm{Zr}, \mathrm{TR}, \mathrm{U}\end{array}$ \\
\hline $\begin{array}{l}\text { Ultra- } \\
\text { meta- } \\
\text { mor- } \\
\text { pho- } \\
\text { genic }\end{array}$ & 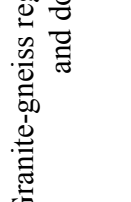 & & $\begin{array}{l}\text { Autochtho- } \\
\text { nous granite } \\
\text { massifs }\end{array}$ & Ceramic pegmatites & $\begin{array}{c}\text { Oligoclase } \\
\text { Microcline-oligoclase } \\
\text { Microcline } \\
\text { Albite- microcline-oligo- } \\
\text { clase }\end{array}$ & $\begin{array}{c}\text { Barren; } \\
\text { Ceramic raw material; } \\
\text { geochemical specialization } \\
\text { in } \mathrm{Nb}, \mathrm{Zr}, \mathrm{TR}, \mathrm{U}\end{array}$ \\
\hline & 0 & & Migmatite & & & \\
\hline
\end{tabular}


trusive alkaline massifs; multi-phase granite batholites.

By the nature of pegmatite-bearing structures, we distinguish the following structural groups: granite-gneiss regional structures and domes; domesynclinore and dome-trough plume-structures (subgroups: intradome synclinore and trough, in particular greenstone structures; intrusive domes and batholites); specific tectonic zones of stress.

Associations (according to (Ginzburg, 1979) formations) and mineralogical-geochemical and ore types of pegmatites are singled out after (Ginzburg, 1979, Kuz'menko, 1978, Nikanorov, 1979, Petrov, 1975, Shavlo, 1984, Shmakin, 1987and others) on the basis of characteristic mineralogical and geochemical features of pegmatites.

The offered scheme is rather cumbersome; however it allows us to present gradual development of pegmatite formation with the change of associations and types of pegmatites in the full tectonic-magmatic cycle of megastructure formation, as well as the development of the pegmatite process in one range of pegmatite associations connected with the development of granitoid process within megastructures (ceramic pegmatites $\rightarrow$ uranium-rare earth $\rightarrow$ rare metal $\rightarrow$ thoria-rare earth $\rightarrow$ miarolitic and chamber pegmatites) and ranges of types of pegmatites associated with the development of pegmatite associations during one period of megastructure establishment.

Wesingleoutaseparategroupofmetamorphogenicmetasomatic pegmatites spread within specific tectonic zones of stress (pressure structures in edge zones of shields and zones of tectonic-metamorphic activization of granite-gneiss domes and others) and composed of formations of muscovite and berylmuscovite pegmatites. These pegmatites within the Ukrainian Shield, in our opinion, are not revealed, as those pegmatites with high (up to $30 \%$ ) content of muscovite (Mokromoskovske pegmatite field), that we personally researched, are obviously primary unchanged rocks with abnormal content of muscovite that formed during crystallization in the closed system of pegmatite vein separated from parent massif.

\section{References}

Bobrov, O. B., Sivoronov, A. O., Maljuk, B. I., Lysenko, O.A. 2002. Tektonichna budova zelenokam'ianykh struktur Ukrainskoho schita [Tectonic structure of greenstone structures of the Ukrainian Shield].Collection of Scientific Papers of UkrDGRI.№1-2. 46-67 (In Ukrainian).
Voznyak, D. K., Pavlyshyn, V. I. 2001. Vysokotermobarychni potoky ridkogo $\mathrm{CO}_{2}$ ta ih rol u mineraloutvorenni (na prykladi Ukrainskoho schita) [High-thermobaric currents of liquid $\mathrm{CO}_{2}$ and their role in mineral formation (on the example of the Ukrainian Shield]. Mineralogical Journal (Ukraine). Vol. 23. No 4. C. 12-18. (In Ukrainian)

Ginzburg, A. I., Timofeev, I. N., Feldman, L. G. 1979. Osnovy geologii granitnyh pegmatytiv [Fundamentals of granite pegmatite geology]. Moscow. 296 p. (In Russian).

Drannyk, A. S., Kostenko, M. M., Yesypchuk, K. Yu. and oth. 2003. Heoloho-strukturne raionuvannia Ukrainskoho shchyta dlia utochnennia stratyhrafichnoi koreliatsii dokembriiskykh utvoren [Geological-structural regionalization of the Ukrainian Shield for adjustment of stratigraphic correlation of Pre-Cambrian formations]. Mineral Resources of Ukraine.№1. 26-29 (In Ukrainian).

Yeryomenko, G.K., Ivanov, B.N., Belyh, A.N. and oth. 1996. Mineralogicheskie osobenosti i uslovia obrazovania litievyh pegmatitov Kirovogradskogo bloka (Ukrainski schit) [Mineralogical features and conditions of formation of lithium pegmatites of the Kirovogradski block (Ukrainian Shield)]. Mineralogical Journal (Ukraine). Vol. 18.№1.P. 48-57. (In Russian).

Ivanov, B.N., Makivchuk, O.F., Bugayenko, V.M. and oth. 2002. Osnovni typy ridkisnometalnyh rodovysch i rudoproiaviv zahidnoi chastyny Kirovogradskogo bloku [Main types of rare metal deposits and ore occurrences of the Western part of the Kirovogradski block]. Collection of Scientific Papers of UkrSGPI. № 1-2. P. 116-127. (In Ukrainian)

Isakov, L. V., Bobrov, O. B. 2011.Heoloho-strukturni ta mahmatychni osoblyvosti formuvannia pehmatytiv Inhulskoho mehabloka [Structural and magmatic features of formation of Ingulski megablock pegmatites].Collection of Scientific Papers of UkrSGPI. 1. 21-34. (In Ukrainian)

Isakov, L. V., Bobrov, O. B., Paran'ko, I.S., Shpylchak, V. O., Shurko M. M. 2011. Zakhidne Pryazov'ia samostiinyi mehablok Ukrainskoho schita [Western Pryazovia - a separate megablock of Ukrainian Shield] Collection of Scientific Papersof UkrSGPI. 4. 122-133. (In Ukrainian)

Isakov, L.V. 2006. Do pytannia genezysu ta klasyfikatsii granitnyh pegmatitiv [On the genesis and classification of granite pegmatites of Pre-Cambrian Shields]// Collection of Scientific Papers of UkrSGPI. - № 4. - P. 37-45. (In Ukrainian)

Isakov, L. V. The origin of megastructures of the Ukrainian Shield in view of the magmatic plume concept. Dniprop.Univer. Bulletin, Geology, geography, 25(2), 58-72.

Isakov, L. V., Paran'ko, I. S., Bobrov, O. B., Shpylchak, V. O., Lypchuk L. V., Yelkina I. B., Shurko M. M. 2012. Do pytannia vydilennia v mezhah Zahidnopryazovskogo geobloka yanvarskogo granitnogo 
kompleksy yak skladovogo elementu evolutsii zelenokamianyh struktur Zahidnogo Pryazovia [On the issue of distinguishing Yanvarski granite complex within the Western Pryazovia geoblock as a constituent element of evolution of greenstone structures of Western Pryazovia]. Collection of Scientific Papers of UkrSGPI. № 3. P. 11-26. (In Ukrainian).

Isakov, L.V. 2013. Systematizatsia pegmatytiv Ukrainskogo schita za geologo-strukturnymy osoblyvostiamy formuvannia pegmatytonosnyh granitnnyh kompleksiv [Systematization of pegmatites of the Ukrainian shield by geological-structural features of formation of pegmatite-bearing granite complexes]. Collection of Scientific Papers of UkrSGPI. № 3. P. 9-25. (In Ukrainian).

Kuz'menko, M. V. 1978. Geohimia tantala i genesis tantalovyh mestorozhdenii[Geochemistry of tantalum and genesis of tantalum deposits]. Moscow. 214 p. (206) (In Russian).

Mineralogia i genesis kamernyh pegmatitov Volyni [Mineralogy and genesis of chamber pegmatites], 1973 / Lazarenko E. K., Pavlishyn V. I., Latysh V. T., Sorokin Yu. G. Lvov. 359 p. (In Russian).

Nikanorov, A. S. 1979.Granitnye pegmatity [Granite pegmatites]. Moscow. 168 p. (In Russian).

Petrov, V.P. 1975. Sovremennoe sostoianie problemy genesisa muskovitovyh pegmatitov [Modern state of the problem of muscovite pegmatite genesis].
Muscovite pegmatites of the USSR. Leningrad. P. 56-62. (In Russian)

Rozanov, K.I., Lavrinenko, L.F. 1979. Redkometalnye pegmatity Ukrainy [Rare metal pegmatites of Ukraine]. - Moscow. 139 p. (In Russian)

Sivoronov, A. A., Sirota, M. G., Bobrov, A. B, 1983. Tektonicheskoestroenie fundamenta Srednepridneprovskojgranit-zelenokamennoj oblasti [Tectonic structure of the foundation of the Middle Prydniprovian granite-greenstone area]. Geological Journal. V. 43. No 6. P. 52-64.(In Russian)

Tektonichna karta Ukrainy. Masshtab 1:1 000 000. 2006. [Tectonic map of Ukraine scale 1:1 000 000]. Chiefed. Kruglov S. S. Kyiv: Geoinform. (In Ukrainian)

Shavlo, S. G., Kirikilitsa, S. I., Kniazev, G. I. 1984. Granitnye pegmatity Ukrainy [Granite pegmatites of Ukraine]. Kyiv. 263 p. (In Russian)

Shmakin, B.M. 1987. Pegmatitovye mestorozhdenia zarubezhnyh stran [Pegmatite deposits of foreign countries]. Moscow. 224 p. (In Russian)

Shcherbakov, I. 2005. Petrologija Ukrainskogo schita. [Petrology of the Ukrainian Shield]. Lvov. 366 p. (In Russian)

Shcherbak, N.P., Artemenko I.M., Lesnaia, I.M., Ponomarenko A.N. 2005.Geohronologija rannego dokembrija krainskogo shhita [Geotechnology of the early Pre-Cambrian Ukrainian Shield]. Kyiv. 243 p. (In Russian) 